\title{
Kéri Katalin
}

keri.katalin@pte.hu

\section{A tananyagról...}

A kurzus a Nevelés- és müvelődéstörténet, illetve a könyvtártörténet hazánkban kevéssé ismert területével, a középkori iszlám könyvtáraival foglalkozik. Az iszlám kialakulásának rövid áttekintése után a világvallás tudásról, olvasásról tartott nézeteit összegzi a tananyag, majd ezt követően az arab írás kialakulásának és használatának rövid története, az olvasás és a könyvkultúra középkori históriájának bemutatása következik. A tananyag-modul középpontjában a középkorban fontos mủvelődési-tanulási helyszínként szolgáló keleti és nyugati könyvtárak megszületésének, müködésének és hanyatlásának összevető, forrásrészletekkel gazdagított, sok hiteles adattal alátámasztott leírása áll. Ez a tananyagrész szervesen kapcsolódik az osztatlan tanár szakos hallgatók Nevelés- és művelődéstörténet című kurzusának diakrón és szinkrón szempontokat egyszerre érvényesítő, a nevelés múltját komplex módon, összehasonlító neveléstudományi keretek között áttekintő pécsi tematikájához, az abban található 5. és 6 . tematikus egységhez:

5. A müveltségképek, nevelési eszmények átadásának színterei: az intézményen kívüli és az intézményesült nevelés. Az iskola szervezetének, funkcióinak változásai az egyes korszakokban és földrajzi helyszíneken.

6. Az európai civilizáció: egység és elkülönülés. Egyes korok nevelési-oktatási gyakorlata; oktatási tartalmak, nevelési tervek változása térben és időben; a kultúraátadás, a tanulás tartalmi változásai a történelemben.

\section{Bevezetö gondolatok}

A nevelés- és müvelödéstörténet csakúgy, mint a könyvtártörténet olyan tudomány- és tématerület, amely nem csupán a pedagógusképzésben és/vagy a könyvtár szakon, de tágabb értelemben a bölcsészeti tudományokhoz kapcsolódóan (különösen a történelem, az irodalom, a filozófia esetében) is fontos. Ennek egy igen szük, hazánkban igen 
kevéssé kutatott és tanulmányozott területe a középkori iszlám könyves kultúrájának, tanulási és müvelődési módszereinek, könyvtárainak históriája. A tananyag ehhez a témához ad művelődés-, nevelés-, vallás-, könyv- és írástörténeti keretek közé helyezett áttekintést.

\section{Célok, kompetenciák}

A kurzus tömör alfejezetekbe foglalva, képekkel, forrásrészletekkel és szakirodalmi utalásokkal kiegészítve mutatja be a középkori iszlám könyv- és könyvtártörténetét. A tananyag az iszlám kialakulásával, történetével kapcsolatos alapozó ismeretek mellett a világvallás tudásról, tanulásról, olvasásról, könyvekről vallott nézeteinek áttekintését is adja. A kurzus fö része a keleti és nyugati muszlim területek könyvtárairól nyújt ismereteket, gazdag fogalmi háló köré építve a téma mondanivalóját. A kurzus fejleszti a diákok összehasonlító szemléletét, történelmi látásmódját, forrásfeldolgozási módszereit. A tananyag felépítésénél fogva alkalmas arra is, hogy egy-egy felmerülő kérdés esetén gyors választ kapjon a résztvevő, ezt a logikusan egymás után következő, egymásból kibomló alfejezetek segítik.

\section{Célközönség}

A kurzus szerves kiegészítése lehet mindannak, amit Nevelés- és müvelödéstörténet, illetve könyvtártörténet címü tárgyak keretében a pedagógusképzésben és az informatikus könyvtáros szakon országszerte tanulnak a hallgatók. Eredményesen használhatják továbbá a pályán lévő pedagógusok, könyvtárosok és más bölcsészeti területek müvelöi és közgyüjtemények dolgozói is.

\section{Feldolgozási idö}

Az ismeretek elsajátítása a tananyag fejezeteinek elolvasása után kb. 1 órát vesz igénybe. 


\section{Az iszlám kultúra születése}

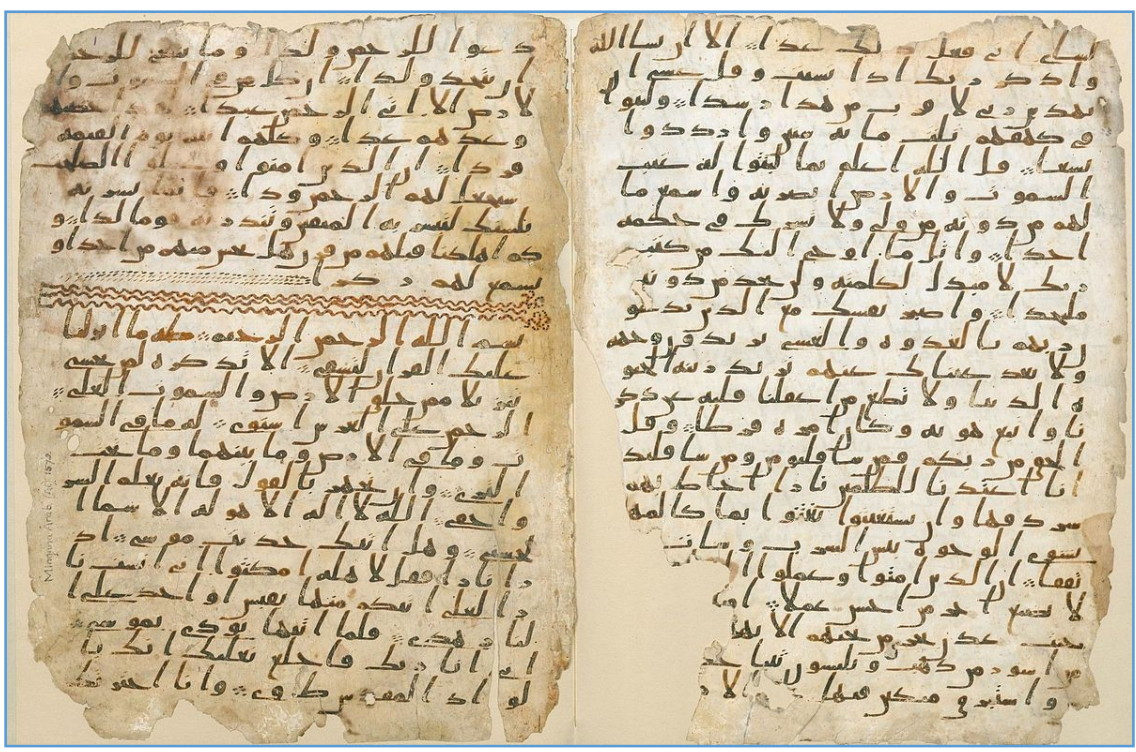

1. kép - A Korán legkorábbi kézirata (7. század)

A „hosszú 6. században” Bizánc és a Szászánida Irán folyamatosan harcban állt egymással. Hadi cselekményeik kapcsán szívesen támaszkodtak egyes észak-arábiai törzsek szolgálataira, jóllehet, a korábbi időszakokban egyik nagyhatalom sem mutatott különösebb érdeklődést Arábia iránt. ${ }^{1}$ Abesszínia, Jemen és Észak-Arábia területének - mint a bizánciak és perzsák között fekvő „harmadik világnak” - jelentőségét nem annyira katonapolitikai, mint inkább kereskedelmi értelemben vett fontossága adta. ${ }^{2}$ Bizáncnak különösen szüksége volt új szárazföldi kereskedelmi útvonalakra, hogy az Ázsiából jövő (luxus)termékekhez hozzájusson, hiszen az Indiai-óceán és a Perzsa-öböl közti vízi utat az irániak uralták. A sivatagi Mekka városa kulcspozícióba került a térségben, a közvetítő kereskedelem kapuja lett, és gazdasági felemelkedésének köszönhetően - az észak-arab térséggel együtt - fontos történelmi szerephez jutott.

- Ez a tananyag a szerzö korábban, önálló formában már megjelent müvének [PTE BTK, NI, Nevelés- és Müvelödéstörténeti Tanszék, Pécs, 2020, ISBN (html) 978963-429-495-5] aktualizált változata. | A szövegben elöforduló összes internetes hivatkozás letöltési és ellenörzési dátuma 2021. május 1.

1 ARMSTRONG, K.: Mohamed. Az iszlám nyugati szemmel. Európa, Budapest, 1998. 78-80. o. Antikvarium.hu: https://bit.ly/3snLAvD | PTE OPAC - 290.6 A 83: https://bit.ly/3ct2zY4

2 SIMON, R.: Korán - A Korán világa. Helikon, Budapest, 1994. 422-423. o. Antikvarium.hu: https://bit.ly/3rq7b59 | PTE OPAC - 290.6 K 70: https://bit.ly/3fijKNw 
Simon Róbert, Karen Armstrong és napjaink más neves kutatói egyaránt úgy vélik, hogy az iszlám születése szorosan összefonódik a város, a térség, illetve Mohamed próféta életének történetével. Az arabság hosszú időn keresztül élt különböző vallású népek mellett, ismerték és tisztelték például a Koránban akhl al-kitáb-nak, vagyis a könyv népének nevezett zsidókat és keresztényeket. A Mohamed próféta által közvetített isteni kinyilatkoztatások azonban minden addigi ismeretnél fontosabb hatást gyakoroltak az arab törzsek gondolkodására, hiszen saját nyelvükön szóltak hozzájuk e revelációk. Ez a hatás természetesen fokozatosan bontakozott ki és terjedt; közismertek a próféta életútjának állomásai, a mekkaiak és medinaiak ellenségeskedései. Mohamed halálakor (632) azonban az iszlám körvonalai már világosan kirajzolódtak. ${ }^{3}$

Ezt követően a muszlimok viharos gyorsasággal, egymás után foglalták el a szíriai, egyiptomi, perzsa sőt egyes dél-európai településeket és egész térségeket (legelsőnek a szír központ, Damaszkusz adta meg magát 635-ben), dacolva Bizánc és Irán ellenállásával. Fennhatóságukat az elfoglalt területeken katonai táborhelyek (amszár) létesítésével próbálták megerösíteni. ${ }^{4}$ Sikereik azonban nem pusztán katonai erejük kifejeződései voltak. A kialakuló iszlám kultúrája képes volt a lehető legkülönbözőbb idegen hatásokat saját keretei között összeötvözni, hallatlan nyitottságról és rugalmasságról téve tanúbizonyságot. Nem erőszakolták a meghódítottak iszlám hitre való áttérését, sőt számos kisebbségi csoportnak védettséget adtak. Az iszlám korai kultúrájára a vallási türelem mellett jellemző volt a régi (antik) tudományok eredményei iránti hallatlan érdeklődés. Az arabizálást sem eröszakolták a meghódított területeken, de a Korán nyelvét minden nyelv elött valónak tartották. Megengedték a szúrák más (pl. perzsa) nyelven való magyarázatát, de elfogadhatatlannak tartották a Korán lefordítását más nyelvekre.

A birodalomépítés szempontjából - akkoriban is - óriási jelentősége volt a minél megfelelőbb jogrend és közigazgatás kialakításának, amely a római jogra, valamint a bizánci és perzsa közigazgatásra is támaszkodva történt meg. Az egyre terebélyesedő birodalom építményén azonban minden törekvés ellenére már nagyon korán repedések keletkeztek. Ennek okai csak részben voltak vallási természetüek: nagyobb problémát jelentett az, hogy Mohamed életében nem alakul-

3 SIMON, R.: Korán - A Korán világa. Helikon, Budapest, 1994. 455. o. Antikvarium.hu: https://bit.ly/3rq7b59 | PTE OPAC — 290.6 K 70: https://bit.ly/3fijKNw

4 Részletesebben lásd: ROGERS, M.: A hódító iszlám. Helikon, Budapest, 1987. 2325. o. Antikvarium.hu: https://bit.ly/3w6wMni | PTE OPAC -290 G 47: https://bit.ly/3w4lEaF 
tak ki az utódlás rendjét megszabó elvek. ${ }^{5}$ A siíták szerint például Mohamed leszármazottait illeti a gyülekezet szellemi fövezérlete, a kalifai (imám) méltóság, szemben az ortodox szunniták elképzeléseivel. ${ }^{6}$

Már a 7. századtól kezdve különböző vallásmagyarázó iskolák jöttek létre, melyek egymás mellett, egymással viaskodva évszázadokon át nagy hatást gyakoroltak a tudományos gondolkodásra is. Nehezítette a helyzetet az, hogy a próféta által kinyilvánított szövegek lejegyzésére zömmel csak halála után került sor, hiszen amíg ő és tanítványai éltek, az orális hagyományozás elsőbbséget élvezett az írásbelivel szemben. A Korán végleges változatának kialakítása csak a 10. századra fejeződött be. ${ }^{7}$

\section{A tudás, a tanulás fontossága}

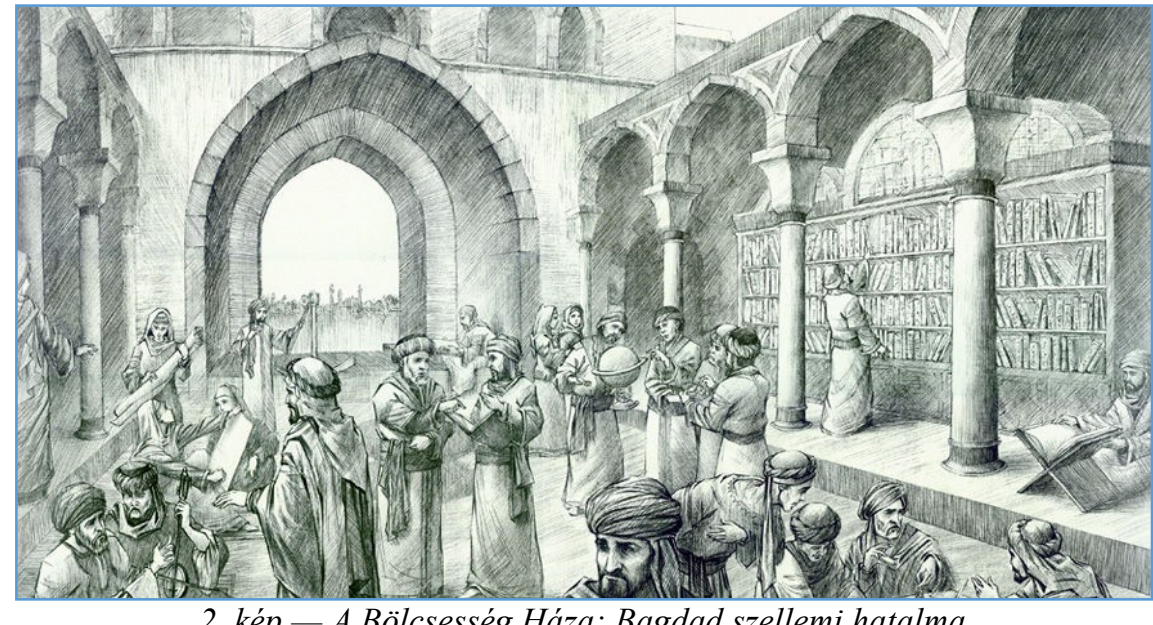

2. kép - A Bölcsesség Háza: Bagdad szellemi hatalma

Az arabok, történetüket két részre bontván, az iszlám előtti időket a tudatlanság kora (al-dzsahilijja) néven tartják számon. Az iszlám világában a kezdeti időszaktól fogva a tudás, a tanulás alapját a prófétai kinyilatkoztatás jelentette. Egy muszlim mondás szerint: „Az emberek kétfélék: olyanok, akik tanulnak, s olyanok, akik tudnak. Akik e két csoport egyikébe sem tartoznak, azok mihaszna férgek." A Korán megismerése és recitálása, valamint a hozzáfüzött magyarázatokból

5 ROGERS, M.: A hódító iszlám. Helikon, Budapest, 1987. 31-31. o. Antikvarium.hu: https://bit.ly/3w6wMni | PTE OPAC — 290 G 47: https://bit.ly/3w4lEaF

6 GLASENAPP, H.: Az öt világvallás. Gondolat, Budapest, 1987. 410-411. o. Antikvarium.hu: https://bit.ly/31qK4Nj | PTE OPAC - $290 \mathrm{G}$ 47: https://bit.ly/3w4lEaF

7 Lásd erröl: SIMON R. i. m. 460-476. o. Antikvarium.hu: https://bit.ly/3rq7b59 | PTE OPAC — 290.6 K 70: https://bit.ly/3fijKNw 
álló hadísz ismerete minden muzulmán számára nélkülözhetetlen volt. Valamennyi tudomány müvelését azért tartották fontosnak, hogy segítségükkel a vallásos tanításokban minél jobban elmélyülhessenek. A tudományok rendszerezésére irányuló számtalan iszlám törekvés is e gondolat ismeretében érthető meg. ${ }^{8}$ A tudományok rendszerét - az általuk megjelölt sorrendtől függetlenül - valamennyi muszlim tudós úgy képzelte el, mint egy képzeletbeli növény testét, amelynek ugyan önálló ágai és levélkéi vannak, de azok elválaszthatatlanul egymáshoz kapcsolódnak, és a hierarchikus rendszer csúcspontján a teológia áll.

A muszlim tudósok tehát - bár érdeklődésük homlokterében mindig elsősorban a Korán és annak értelmezése állt - már a 7. századtól kezdve elkezdtek intenzíven foglalkozni különböző tudományok eredményeinek megismerésével és kutatásával. Már az iszlám korai századaiban megkezdődött más népek tudományos műveinek perzsa és arab nyelvre fordítása, és valóságos értékké vált a tanulás, a tudományokkal való foglalkozás. Az ókori görög és római, a kínai és indiai és egyéb kultúrák eredményeinek átvétele és egybegyúrása jelentette a muszlimok hihetetlenül gyors és látványos kulturális felemelkedésének alapját, sőt - az Ibériai-félszigeten és Dél-Itálián keresztül begyürüző müvek és gondolatok hatására - ez lett a középkori európai kultúra kibontakozásának is az egyik legfontosabb mozgatórugója.

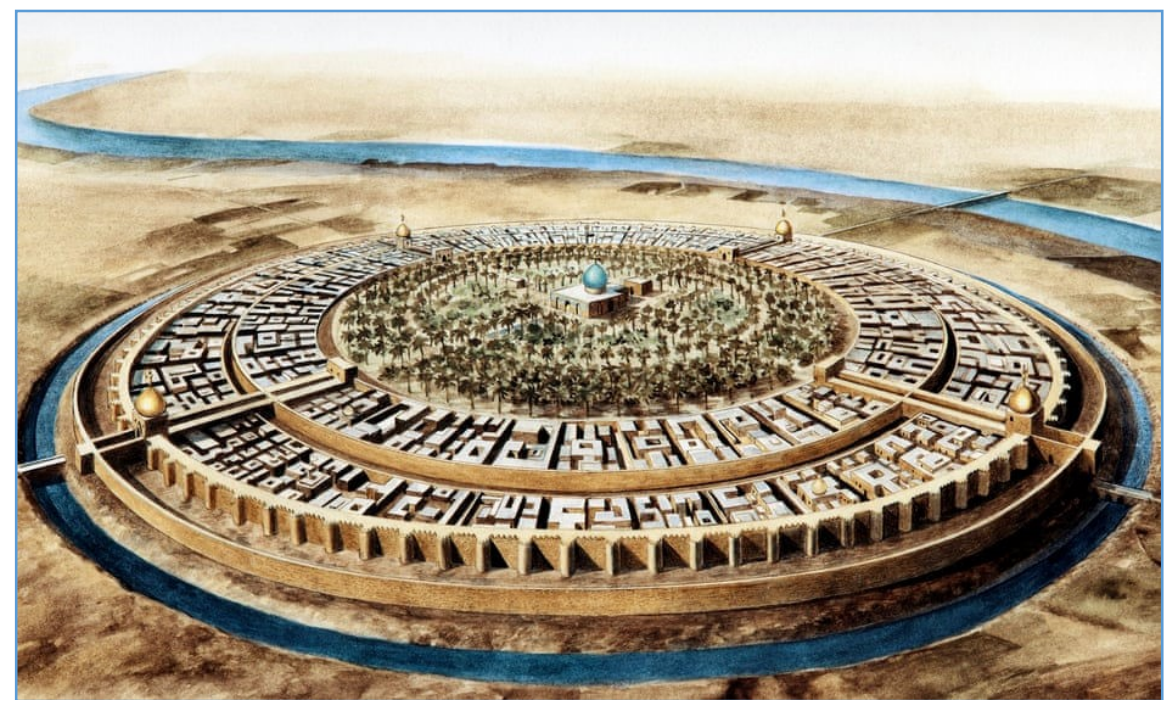

3. kép - Bagdad kerek városa a 10. században, az Abbaszida-kalifátus csúcsa

8 Lásd erről: KÉRI, K.: Rendszer és tudás. Iskolakultúra (ISSN 1215-5233), VII. évf., 1997/október, 10. sz., 110-114. o. PTE PEA: https://bit.ly/3dfuiKT | Kerikatalin.wordpress.com: https://bit.ly/3u09LR4 
Ennek hátterében állt - a Korán megértésére való törekvés mellett - az a tény is, hogy az arabság nagy része életformát váltott. A korábban nagyrészt sivatagi nomád törzsek leszármazottai az elfoglalt területek újonnan létesített garnizonjaiban és régi városaiban új, korábban ismeretlen problémákkal kerültek szembe. A városi együttélés kereteinek és szabályainak kidolgozása, a kereskedelem, az állam- és a hivatalszervezés működtetésével járó feladatok megoldása, az építkezések megszervezése számos új teendőt teremtett.

A 9-10. századtól kezdve az iszlám keleti és nyugati felében is széles körben kibontakozott az intézményesült oktatás, és feltételezhetjük, hogy az Ibn 'Abd Rabbihi által megfogalmazott kívánság sokak tetszésével találkozott: „A tudás legyen gazdagságod, a nevelés a te díszed!” A Koránban is számos helyen olvasható a tudás, a tanulás méltatása, mint azt például az alábbi idézet is tanúsítja: „Allah annak adja a bölcsességet, akinek akarja. Akinek pedig bölcsesség adatik, annak nagy jó adatott."

\section{Az írás és az íráshordozók}

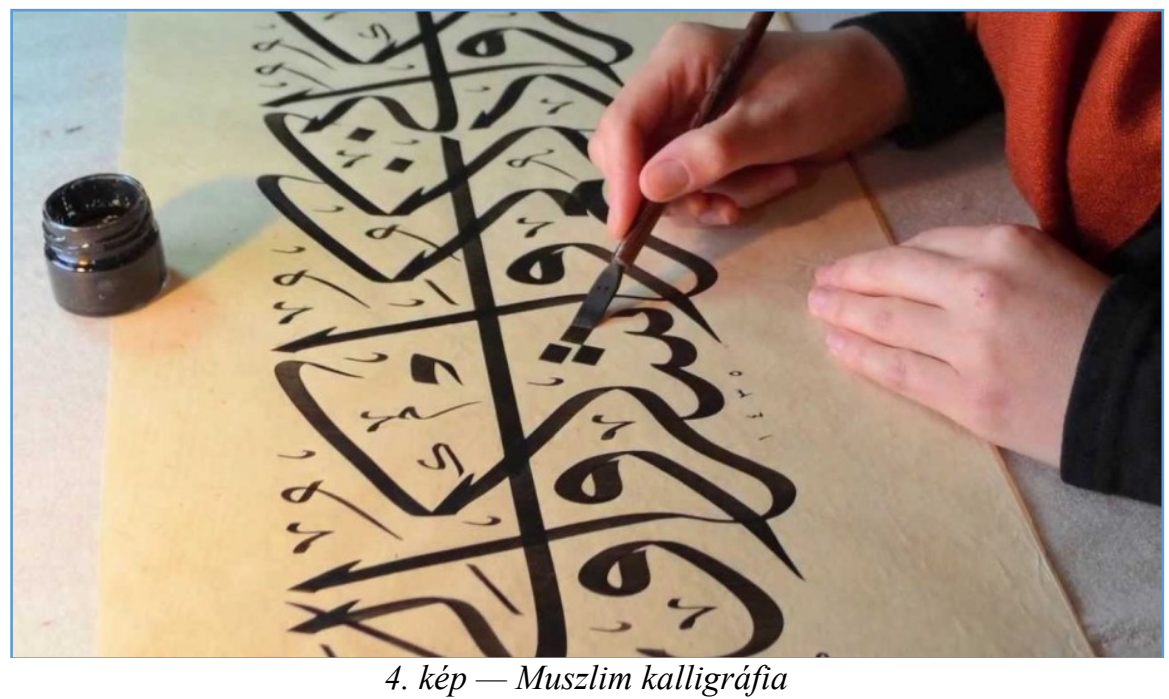

A letelepedéssel összefüggő jelenség volt a szóbeli információ-őrzés és ismeretátadás mellett megjelenő írásos források számának növekedése is. A régi és új városokban - összefüggésben az adminisztrációs feladatok sokasodásával illetve az iskolák számának robbanásszerü növekedésével - egyre több írástudóra volt szükség. A 14. századi

9 Korán, 2, 269. 
moszlim szerző, Ibn Khaldún is kiemelte művében azt, hogy bizonyos (kifinomult) mesterségek, mint például a kalligráfia megjelenése főként a városi kultúrához köthetö. Mivel pedig az írás városi jelenség, szerinte ,....azt találjuk, hogy a legtöbb beduin írástudatlan: nem tudnak írni és olvasni."10

A 19. században alakult ki az a nézet, mely mind a mai napig tartja magát, hogy az arab nyelv a nabati írásból alakult ki az i. sz. 6. századra. ${ }^{11}$ Emellett feltételezhető még az arab nyelv kialakulásával kapcsolatosan a palmyrai hatás is, mely nem zárja ki az előző eredetmagyarázatot, lévén hogy az arab nyelv története esetében is egy hosszú, bonyolult folyamatról van szó. Az arab írás fó jellemzői, a betüknek és a mellékjeleknek a rendszere a 8 . századra teljesen kialakult. A mássalhangzókat és hosszú magánhangzókat jelölő arab írás nem tökéletes betűírás. Ráadásul számos betűt csak különböző számú pontok különböztetnek meg egymástól, amely pontok az írás során akár el is maradtak, csakúgy, mint a magánhangzók jelölése. Éppen ezért jelentős mértékü volt mindig is a beszélt és írott nyelv közötti kettősség. E jelenségből eredeztethető valószínüleg az arab írás misztikus felfogása, az a köznapi jelentésen túlmutató gondolat, hogy minden mást jelent, mint aminek látszik. ${ }^{12}$

A kalligráfia, a szépírás mestersége (művészete?) az iszlám világban mindig is igen nagyra becsült foglalatosság volt, művelöit megbecsülték. A jobbról balra, fentről lefelé vezetett folyóírás, a sok díszítő elemmel tarkított szépírás valóban müalkotásnak tetszik a régi műveket szemlélve. A kalligráfiáról úgy tartották, hogy a „lélek geometriája”. Ibn Rabbihi azt írta egy müvében, hogy az írás: „A kéz nyelve, a tudat szépséges kifejeződése, az értelem követe, a gondolkodás visszhangja és a tudás fegyvere."13

Az iszlám elötti időkből leginkább kőbe, sziklába vésett feliratok maradtak ránk, majd - az iszlám kultúra 3. századáig - a pergamen és a papirusz voltak a legfőbb íráshordozók. A legjobb minőségü pergament a legfehérebb, legrugalmasabb és legfinomabb borjúbörből készítették. Egy költő szerint a pergamenkészítés ugyanolyan fáradtságos munka volt, mint a cserzővarga tevékenysége. Córdobában a 10. században volt egy Rabad al-Raqqaquin nevű kerület, melyet tel-

10 IBN KHALDÚN: Bevezetés a történelembe. Osiris, Budapest, 1995. 414. o. Antikvarium.hu: https://bit.ly/39jhstT | PTE OPAC — $930 \mathrm{~K} 44$ : https://bit.ly/3tRdVea

11 DÉVÉNYI, K. - IVÁNYI, T.: Az arab írás története. Körösi Csoma Társaság Keleti Nyelvek Kollégiuma, Budapest, 1987. 19. o. Antikvarium.hu: https://bit.ly/3u031Bz

12 Uott, 187. o.

13 MOLINA, M. A.: Córdoba de los Omeyas. Planeta, Barcelona, 1994. 114. o. AbeBooks.co.uk: https://bit.ly/3u2XIT1 
jesen benépesítettek a pergamen-készítők. ${ }^{14}$ Pergamenre elsősorban a Koránt másolták és más, fontosabb írásokat. A 11. századtól a drága, nehéz munkával elöállított pergament teljesen kiszorította a papír. A pergamentől eltérően a papirusz - mely elsősorban Egyiptom területéről származott - föként a hivatali élet során használatos íráshordozó volt. A papirusztekercsekre írt arab nyelvü írások egyébként a 14. századig léteztek, ami bizonyíték arra, hogy az olcsóbb papír nem szorította ki teljesen a papirusznádból készült íróanyagot.

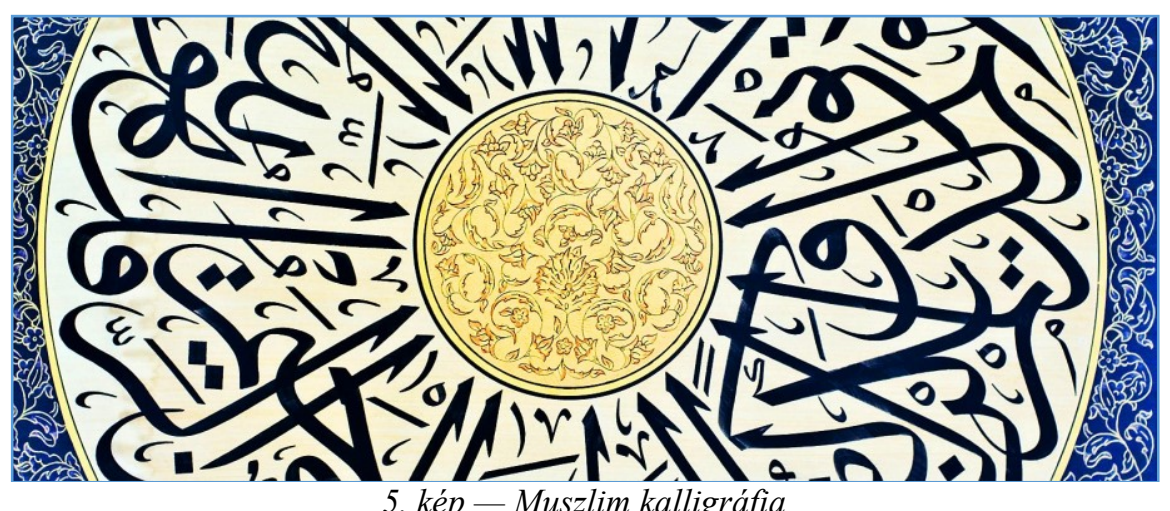

A muszlimok a 8. század során ismerkedtek meg a kínai papírkészítés titkával. Bár a papírgyártást már a 2. században feltalálta egy Ts'ai Lun nevü kínai mandarin, 600 évig sikerült titokban tartani ezen íráshordozó anyag készítésének folyamatát. A muszlimok 751-ben, Szamarkand városát elfoglalva, az ott ejtett hadifoglyoktól tanulták el a papírgyártást. ${ }^{15}$ Még ugyanebben az évszázadban Bagdadban is létesítettek papírmalmokat, és Harún al-Rasíd bagdadi kalifa vezírje, bizonyos Dzsafár a hivatalokban kötelezővé tette a papír használatát a pergamen helyett. Más muszlim városokban is malmok ezrei létesültek, és a selyemhez hasonló vékonyságú, viszonylag olcsón és könnyen előállítható papír világhódító útjára indult. A papírhasználat terjedését valószínüleg az is elősegítette, hogy az erre az anyagra írott Koránszövegekbe nem lehetett belejavítani, mivel az meglátszott (szemben a pergamenröl kivakart és megmásított szövegekkel). Az arabok különböző újításokat kísérleteztek ki a papírkészítés során, és pontos középkori leírások maradtak fenn a technológiát illetően. Az alábbi részlet például azt mutatja, hogyan kellett előkészíteni a papírt a Ko-

14 MOLINA, M. A.: Córdoba de los Omeyas. Planeta, Barcelona, 1994. 115. o. AbeBooks.co.uk: https://bit.ly/3u2XIT1

15 TEVAN, A.: A könyv évezredes útja. Gondolat, Budapest, 1984. 53. o. Antikvarium.hu: https://bit.ly/2NYxsdn | PTE OPAC — 002 T 48: https://bit.ly/3suZrjF 
rán-kódex elkészítéséhez: „Az írnok feltesz a tüzre egy fazék keményítőt, 1:10 arányban higítva vízzel, felforralja, amíg a színe megvörösödik. Azután bevonja az írás számára kiszemelt papírt ezzel a keverékkel, és két napig hagyja száradni. Majd elővesz némi finom timsót és tojásfehérjét, s jól összevegyíti. Újból bevonja a papírt ezzel a keverékkel, és egy napig hagyja száradni. Aranyfényező kővel lecsiszolja a papírt, hogy finom, puha legyen, és lehessen rá írni."16

Miként Molina írja, a középkori iszlám világában a papír színének is szimbolikus jelentősége volt, csakúgy, mint az egyes ruhadaraboknak. A kék szín a gyászt fejezte ki, a piros és a rózsaszínủ az öröm és a hatalom szimbólumai voltak. Csak a legmagasabb méltóságok viselői írhattak ilyen színủ papírra, illetve a kalifákhoz intézett folyamodványok kerülhettek ezekre. A sárga színü - sáfránnyal megfestett - papírokra Córdobában a müvelt és előkelő hölgyek írták leveleiket. ${ }^{17}$

Az írásművészet szempontjából nem csupán a papír minősége és színe számított, hanem fontos volt az íróeszközök milyensége és a kalligráfus felkészültsége, beleértve még a helyes ülésmódot és testtartást is. Az írótoll, a kalam kemény, kihegyezett nád volt, lehetőleg Babilónia árterületeiről való. Az al-Kurtubi nevü szerző szerint (10. század) háromféle toll van: az első toll Allah tolla, a második az angyaloké, a harmadik pedig az embereké. Abu Hafsz al-Andalúszi költeménye szerint: „Milyen csodás dolog is a toll! Sötétséget iszik és fényt áraszt a szája"18 - vagyis költeményében kifejezte az írószerszám tudásterjesztésben betöltött szerepét. A korabeli kalligráfusok tollaikat tolltartókban tartották, és ránk maradtak olyan leírások, amelyek pontos képet közvetítenek egy-egy ilyen tolltartó „tartalmáról”: a kések, tintatartók, késélesítők, hegyezők, ollók és vonalzók, írópapírok világáról.

$\mathrm{Az}$ írás másik elengedhetetlenül fontos kelléke volt a tinta, amelynek szintén több változata ismeretes volt az iszlám írásmü- és könyvkészítői között. A madad nevüt mézzel és gumival elkevert koromból készítették, míg a hibr a fák oldalán található, rovarpetéket tartalmazó gubacsokból, makkokból, tamariszkusz bogyókból készült. A tintakészítés során használtak még tojásfehérjét, birkagyapjút és homokot is, mint adalékanyagokat, valamint színezékeket a sárga, vörös, arany, ezüst, kék, zöld és egyéb színü tinták elöállításához.

Egy-egy kalligráfusnak a tolltartó mellett elengedhetetlen munkaeszköze volt a tintatartó, amely készülhetett rézből, cserépből vagy porcelánból, és mindig ott fityegett az írnok övén.

\footnotetext{
16 Idézi: DÉVÉNYI-IVÁNYI i. m. 67. o.

17 MOLINA i. m. 116. o.

18 Idézi: DÉVÉNYI-IVÁNYI i. m., 55. o.
} 


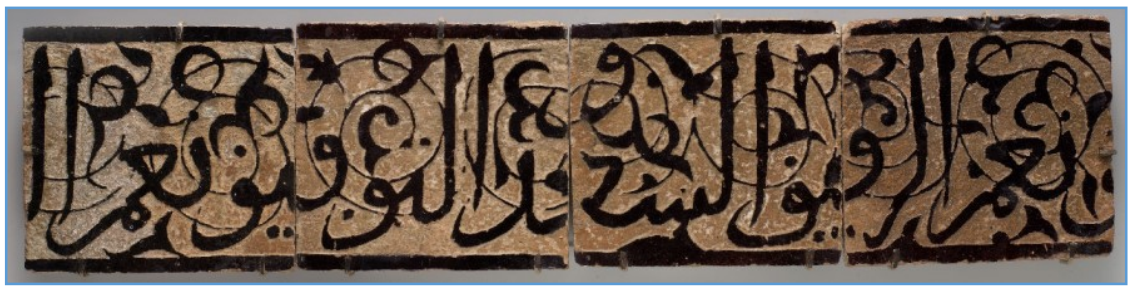

6. kép - Muszlim kalligráfia

Látható tehát, hogy az iszlám korai időszakában is használatosak voltak különféle íráshordozók, a technikák tökéletesedése, a sokféle minőségű papír és tinta elterjedése, a kalligráfusi munka kibontakozása azonban szorosan egybefügg a muszlim kultúra fejlődésével és virágzásával. Az az igény, hogy mind több és több információt feljegyezzenek, és generációról generációra írásos formában is átadjanak, a letelepült életforma velejárója volt. Egyben harc az idővel és az elmúlással, szembeszállás a pusztulással és a pesszimizmussal. Azok a férfiak és nők ugyanis, akik az iszlám másolómühelyeiben tízezrével készítették a könyveket és egyéb iratokat, hittek a jövőben és értékelni tudták a múltjukat is. Nem egy esetben egy-egy másoló nem is értette az általa lemásolt szöveget, de tudatában volt munkája fontosságának. Az évek, évszázadok múlását ugyanis a vallásos és tudományos szövegek java része csakis úgy élhette túl, ha lemásolták őket, lehetőleg minél több példányban.

\section{Könyvek: könyvkészítés és könyvterjesztés}

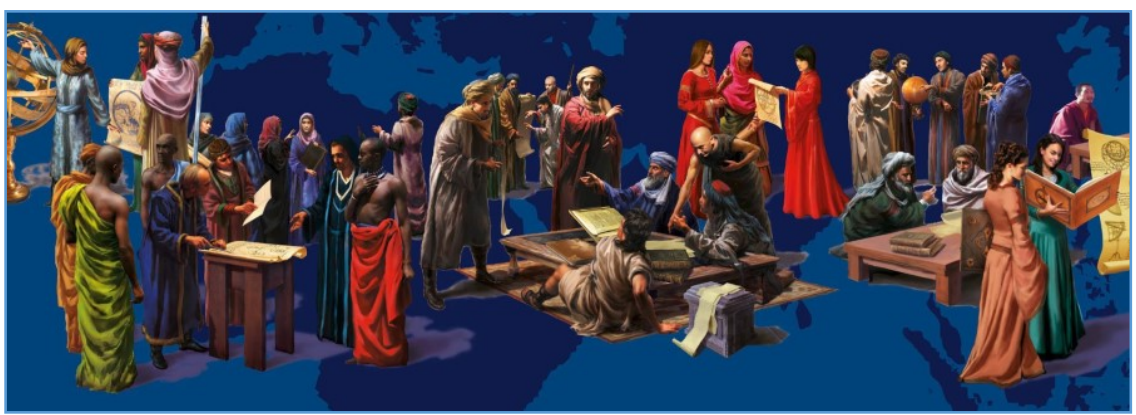

7. kép - Az Iszlám aranykora

Az iszlám világában a Korán első példányai voltak a legelső könyvek. A tudás utáni vágy és a könyvek szeretete azonban nem az iszlámmal jelent meg, a muszlimok körében csak kiteljesedett az, ami már korábban is jellemezte a szír, perzsa és más tudományos központokat. A kínai, szanszkrit és iráni művek már az iszlám korai százada- 
iban lefordításra kerültek, majd ezt követték a görög és római filozófusok, matematikusok, csillagászok, orvosok és más tudósok írásai.

Az araboknak számos lehetőségük volt arra, hogy az olvasás, a könyvek szeretetét megtanulják, hogy az írás, a könyv jelentöségét felismerjék. Az iszlám előtti idők különböző kultúráinak meséiből merítő, egységes óriási gyüjteménnyé formált „Ezeregyéjszaka” számos történetéből kiderül, hogy a mesék egyes szereplői tudtak és szerettek olvasni - már Mohamed megjelenése előtt. A mesemondó Sehrezádról például így szól a mesefolyam egyik változata: „sok könyvet, krónikát olvasott, régi királyok történetét, regéket letünt idők népeiről; mondják, hogy ezernyi könyvet gyüjtött össze, régi nemzedékekről és hajdani királyokról szóló históriákat meg költők müveit."19

A mesegyüjtemény egyik történetében így dicsöítette egyik szereplö a (könyv)írást:
„Meghal minden író, elássa az Idő,
De az, amit leírt, idővel egyre nő.
Ezért, amit leírsz, tökéletes legyen, Ragyogjon a papír a Végítéleten.”20

E történetek, melyekben nem csupán az uralkodók és nagyvezírek, de egyes nők, sőt még a teherhordók is tudnak olvasni, - másodlagos forrásként - mutatják az iszlám által meghódított népek olvasásszeretetét. E szokás már a 8. századtól az arabság körében is visszaköszön, az oktatásügy kibontakozásával és a könyvmásolás fellendülésével, könyvtárak alapításával pedig jelentős lendületet vett a könyvkultúra kibontakozása. A könyvek tanulmányozása nem kevesek kiváltsága volt: sokan hozzáfértek a különböző művekhez, akár olvasóként akár - egyben - tulajdonosként is. Széles körben elterjedt a könyvmásolás- és könyvkötés szokása, egyes értékes példányok akár évszázadokon keresztül is öröklődtek egy-egy családon vagy csoporton belül. Egy 9. századi arab szerző, Dzsáhíz szerint a könyv „a tudás teli zsákja, az okosság és a tudás megőrző edénye."

A madraszák világa, a kalligráfia, a papírkészítés és a muszlim könyvkultúra kibontakozása egymástól elválaszthatatlan jelenségek. A 8. századtól egyre inkább papírra írott szövegek bekötése az ókorban már kidolgozott és megszokott módszereket követte. A papíríveket három vagy öt dupla lapba hajtogatták, és a szövegírás során

19 Az Ezeregyéjszaka meséi. Európa, Budapest, 1974. Fordította: Honti Rezső, 11. o. Antikvarium.hu: https://bit.ly/31vdxFP | PTE OPAC — E 99: https://bit.ly/31onTHF

20 A teherhordó és a három leány története. Fordította: Vajkay Lajos, i. m. Ezeregyéjszaka meséi Uott., 39. o. 
minden egyes ív átmenetekor megjelölték az előző lap utolsó szavát. A könyveket (díszes) bőrbe kötötték. ${ }^{21} \mathrm{~A}$ kéziratos könyvek másolása nagyon fontos, időt, türelmet és felkészültséget kívánó elfoglaltság volt. E művelet egyrészt a mecsetekhez, a falaik között müködő madraszákhoz kötődött. A tanulók másolás vagy diktálás útján jegyezték le egy-egy szerző (a tanár) müveinek szövegét. Jegyzeteiket aztán hitelesítés végett megmutatták a szerzőnek (tanítónak), aki engedélyt (idzsáza) adott rá, hogy a kéziratot terjesszék. Ez nagyon fontos lépés volt a szöveghüség megőrzése miatt.

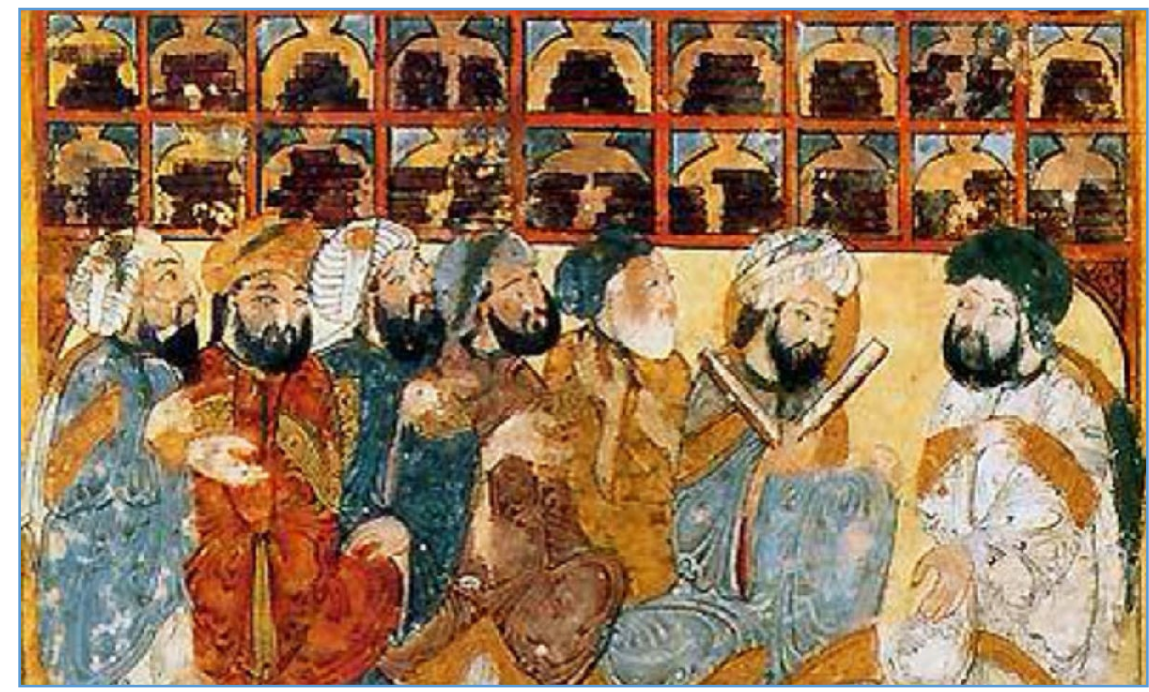

8. kép - 13. századi tudósok egy könyvtárban a Hariri Makamák címü kéziratából

Mivel nem volt mindenkinek alkalma arra, hogy a tág birodalmon belül a leghíresebb oktatási központokat, tanítómestereket felkeresse, számos másolómühely müködött az iszlám valamennyi főbb kulturális központjában, Damaszkusztól Córdobáig, hogy az olvasói igényeket kielégítsék. Az e mühelyekben illetve uralkodói vagy magánkönyvtárakban folyó könyvmásolás kapcsán is ki kell emelnünk az elkészült szöveg hitelességének ellenőrzését, amely munkamozzanatot általában külön ezzel a feladattal megbízott tudós személyek végezték. Nem csupán középkori diákokat és tanárokat találhatunk a másolók népes táborában, hanem a források szerint nem egyszer nagyhírü tudósok is kivették részüket e fáradtságos munkából. Ennek több oka is lehetett: a jeles optikus, a 9-10. század fordulóján élt Ibn al-Haiszám például kenyérkereseti forrásként használta másolói kapacitását, a 13. századi ad-Dahvar orvosi könyvek másolásából élt.

21 DÉVÉNYI- IVÁNYI i. m., 68. o. 
Ezen kívül egy-egy neves szerző vagy tudós azért is vállalkozhatott könyvmásolásra, mert így a saját elméjét is pallérozta, illetve alkalma nyílt személyesen ügyelni a szöveg helyesírására, a szöveghüségre. A 12. században élt nagy hírű tudós, Averroës például több, mint tízezer lapnyi szöveget másolt le élete során. ${ }^{22} \mathrm{~A}$ másolók között nők is akadtak szép számmal, Córdobában például 160 hölgy dolgozott e szakmában a 10. században. ${ }^{23}$

Már a 9. században, az Abbászidák uralkodásának idején megjelentek az első könyvesboltok a bagdadi bazárban. E század végére már száz fölött volt a könyvkereskedők száma csak ebben a városban. ${ }^{24}$ A papír elterjedésével kialakult egy külön szakma, a varrák mestersége, aki egy személyben volt könyv- és papírkereskedő, sőt, akár könyvmásoló és író is. Legtöbb idejét e férfiú a bazár porától távol eső kis boltjában (esetleg a mecsethez illesztett kis bódéban) töltötte, ahol vendégül látott másolókat és vevőket, és ahol az árusításon és másoláson kívül tudományos viták is folytak a müvelt tudósok és tanítványaik között. ${ }^{25} \mathrm{~A}$ régi Kairóban például a 11-12. század fordulóján Ibn Szuráh volt a legjelentősebb könyvkereskedő, aki csakis ritka könyveket forgalmazott, és csak hetente kétszer fogadta a gyüjtőket. Córdobában a 11. században Ibn Abbász, Bagdadban a 14. században a kurd Zain al-Dim al-Amidi volt a leghíresebb könyvárus. ${ }^{26}$ A nagyobb városokban a 9-10. században már olyan sok könyvárusító hely volt, hogy külön negyedet foglalt el a szúk al-varrákín, a könyvesek piaca. ${ }^{27}$

Az a kép, ahogyan a 14. században élt Ibn Battúta vagy a 15 . században alkotó al-Makrízi leírta a kairói könyvpiacot, a nagy magyar orientalista, Goldziher Ignác 20. század eleji utazásáig mitsem változott. Az egyiptomi fővárosban ajándéktárgyak után kutatva Goldziher a könyvesek utcájába jutott: „hol különböző bódékban (dukkan) két igen ellentétes dolgot árulnak: könyvet és papucsot. Sajátságos, hogy a keleti városokban (Szíriában is tapasztalhattuk ezt) e

22 MAZAHÉRI, A.: A muszlimok mindennapi élete a középkorban a 10-től a 13. századig. Európa, Budapest, 1989. 187. o. Antikvarium.hu: https://bit.ly/2QAq6NY | PTE OPAC - 930.8 M 49: https://bit.ly/3919h0a

23 Mủvelt muzulmán nőkről lásd: KÉRI, K.: Nők a fátyol mögött. Valóság (ISSN 03247228), XLI. évf., 1998/augusztus, 8. sz., 64-70. o. PTE PEA: https://bit.ly/3crZOpA | Kerikatalin.wordpress.com: https://bit.ly/2QIFvvU

24 HITTI, P. K.: History of the Arabs. MacMillan, London, 1960. 414. o. Archive.org: https://bit.ly/2PyRziC

25 DODGE, B.: Muslim Education in Medieval Times. The Middle East Institute, Washington, 1962. 14. o. AbeBooks.com: https://bit.ly/3fwGzgT

26 MAZAHÉRI i. m. 188. o.

27 DÉVÉNYI - IVÁNYI i. m., 84. o. 
két árucikket egy és ugyanazon bazárban árulják, s még sajátságosabb az összefüggés oka. A könyveket többnyire vörös börbe kötik, $s$ a papucsok is rendszerint ugyanolyan vörös bőrből készülnek, minőből a könyvek táblái. Igen csábító ugyan itt maradni, hogy valamely értékes buláki nyomtatvány iránt alkuba ereszkedjünk Haszan barátunkkal, a könyvkereskedővel vagy mekkai szomszédjával, ki nekünk a „korán”-on kívül minden könyvet, akár hagyománymüvet, akár a szent Omar ibn al-Farid dívánját mérsékelt vételár mellett átengedni kész, s a keleti kereskedelem kánonjához tartozó alkudozás által igen hosszúra nyújtott vételmüvet tartalma alatt pár tucatszor, mégpedig meglehetős tolakodó módon, kérdezősködik drága egészségünk felől, s ezenkívül a hangulat emelése céljából egypár csésze kávéval és nargilével is kedveskedik." ${ }^{28}$

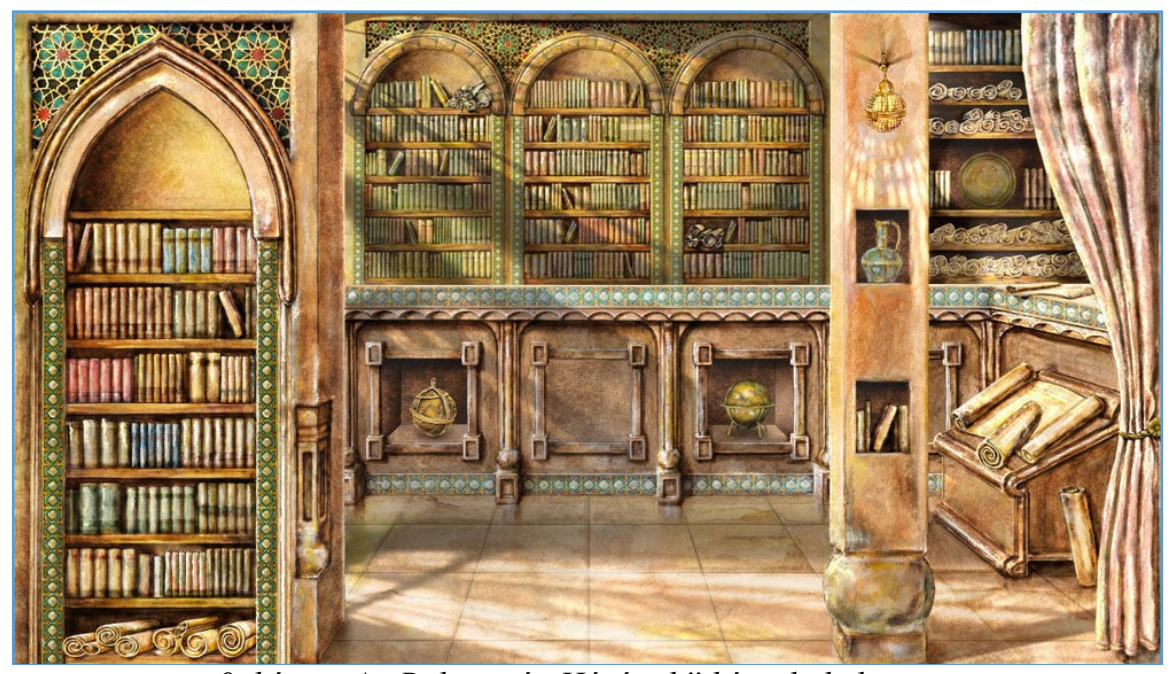

9. kép - A „Bölcsesség Házának” képzeletbeli rajza

Ben Said hasonlóan élénknek írta le egy müvében a kalifátus-korabeli Córdoba könyvpiacát, ahol szintén sok könyvárus kínálta portékáját, és gyakorta tartottak könyvárveréseket. A bibliofil al-Hadrami története az egyik legismertebb forrás, mely idézi az egykori Córdoba könyvpiacának hangulatát: „Jártam egyszer Córdobában, és gyakran kimentem a könyvpiacra, hogy lássam, árulnak-e valami olyan könyvet, amit nagyon szeretnék megvenni. Egy nap aztán, végre elém került egy szépen írott, elegáns kötésủ példány. Nagy volt az örömem. Kezdtem licitálni, de az árverést vezető közvetítő magatartása változott irányomban, mutatván, hogy valaki más jobb árajánlatot tett.

28 GOLDZIHER, I.: Az iszlám. Magvető, Budapest, 1980. 384-385. o. Antikvarium.hu: https://bit.ly/31opflJ | PTE OPAC — 290.6 G 50: https://bit.ly/3tRiDbQ 
Egészen csillagászati összegig vertem fel a könyv árát, jóval felette a kötet igazi értékének. Ám látván, hogy valaki még nálam is többet ajánl, mondtam az árverezés vezetőjének, mutassa meg, ki az a személy. Mutatott nekem egy nagyon elegáns ruházatú férfiút, aki előkelőnek látszott. Közelébe férkőztem, és ezt mondtam neki: - Allah legyen Önnel, doktor úr. Ha elhatározta, hogy ezt a könyvet mindenképp elviszi, én nem makacskodom tovább. Épp eleget alkudoztunk és emeltük az árakat. - Ő erre azt felelte, hogy - Bocsásson meg, de nem vagyok én orvos. Meg sem néztem, miröl szól ez a könyv. De annak, aki szeretne Córdoba elökelőségei közé beilleszkedni, illendő könyvtárat alapítania. A könyvtáram polcai között van még egy üres, ami éppen akkora méretü, mint ez a könyv, és mivel láttam, hogy szépen írott és jóféle kötése van, megtetszett. Az ár nekem nem számít, Allahnak hála, futja a pénzemből ilyenfajta dolgokra." Ezt hallván, én nem bírtam türtőztetni magam, és azt feleltem neki: - Igen, az ilyen embereknek, mint maga, van pénzük. Ám igaz az, amit a közmondás mond: Annak ad diót Allah, akinek nincs foga. Én, aki ismerem a könyv tartalmát, és szeretném használni, szegénységem miatt nem tudok hozzájutni." ${ }^{29}$ Az ilyen - kissé szélsőséges - esetektől eltekintve a könyveknek az iszlám területén többé-kevésbé kiszámítható ára volt. A könyvárak alakulása koronként és helyszínenként természetesen változott, és nagyon sok függött attól is, hogy milyen volt egy-egy mü iránti kereslet, hogy mennyire volt ritka vagy kivételesen szép kivitelezésủ egy könyv. Emelte egy adott kötet árát az, ha maga a szerző készítette, hiszen ő azonnal ellenőrizni is tudta a szöveget. Számított, hogy milyen anyagra és milyen színü, minőségű tintával írták. Nagyon jelentős volt, hogy a könyvmásoló mennyire volt a kalligráfia mestere, alkalmazott-e érdekes, művészi értékủ díszítéseket a könyv elkészítése során. Egyes esetekben a munka gyorsaságát is meg kellett fizetni. A 9. századi Bokharában például 50 és 1000 dinár között mozgott a könyvek ára, ${ }^{30}$ amely adat önmagában is mutatja a rendkívüli eltéréseket.

29 BEN SAID: Maghreb. Spanyolra fordította Ribera y Tarragó, J., spanyolból magyarra fordította Kéri, K. In: SÁNCHEZ-ALBORNOZ, C.: La España musulmana I. EspasaCalpe, Madrid, 1978. 415-416. o. AbeBooks.com: https://bit.ly/2PwBPwK

30 TRITTON, A. S.: Materials on Muslim Education in the Middle Ages. Luzac and Co. Ltd., London, 1957. 195. o. Worldcat.org: https://bit.ly/3cpEelE 


\section{Könyvtárak}

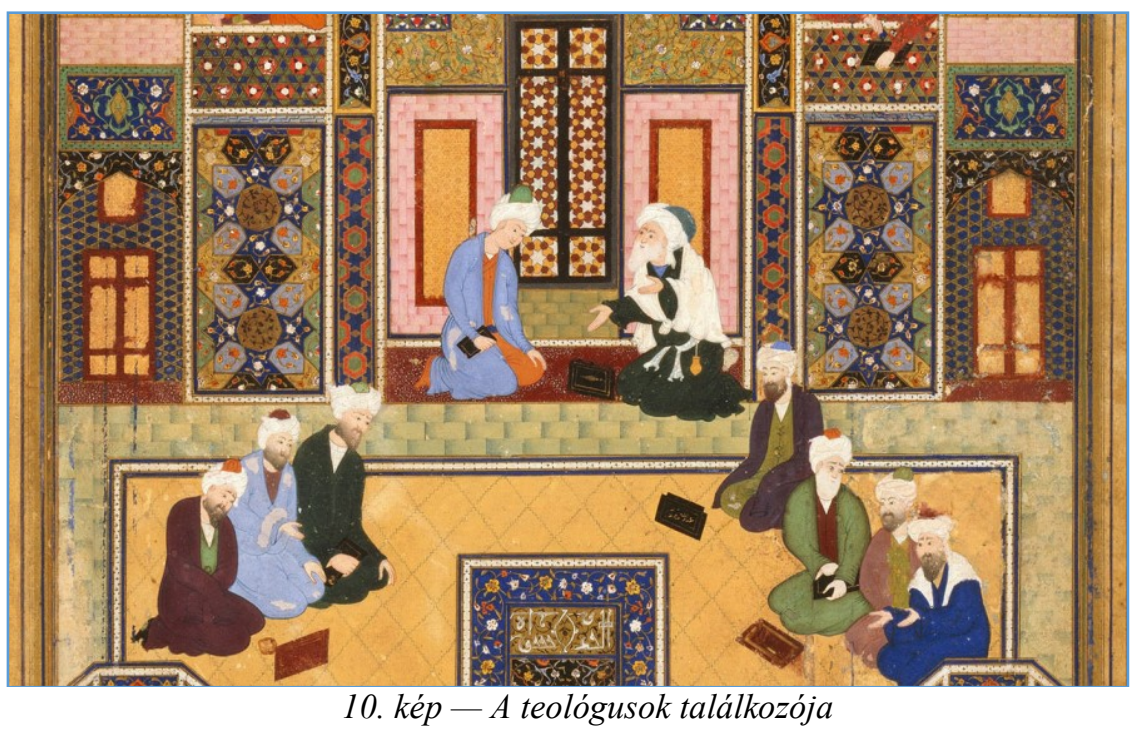

\subsection{Keleti könyvtárak}

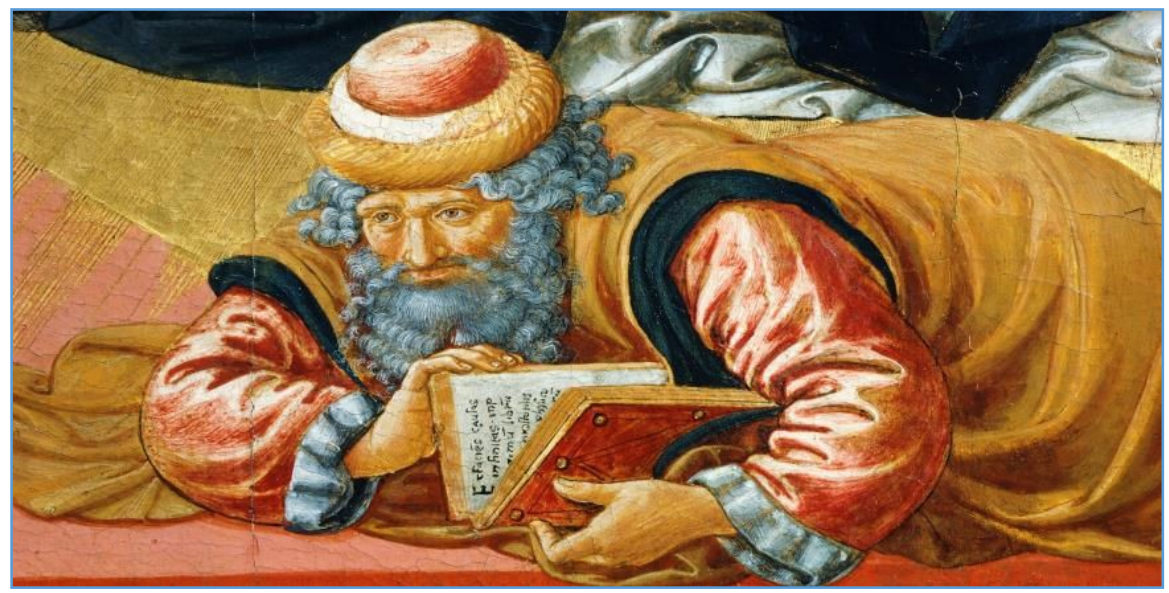

11. kép - Filozófiai nagysága ellenére Ibn Rushdot (Averroës) elbocsátották és irásait elégették. A vád szerint Averroës az ókoriak filozófiáját müvelte az igaz hit rovására.

Az iszlám világának különböző részein, különösen a nagyobb kulturális központokban tehát már a 7-8. századtól széles körben elterjedt az olvasás, a könyvek szeretete. A mecsetekhez valamint a madraszákhoz és más felsőbb szintü oktatási intézményekhez kapcsolódóan fokozatosan gyültek össze a könyvek, melyek egy részét maguk a tudósok és diákjaik másolták, más részük ajándékként vagy hagyaték- 
ként került az „iskolai könyvtárak” állományába. ${ }^{31}$ Számos egyéb, nyilvános vagy fél-nyilvános könyvtár is létrejött, amelyekben olyan olvasmányokat is őriztek, melyek a mecsetek falai között nem számíthattak nagy érdeklődésre, például geometriai, csillagászati, alkímiai vagy zenei témájú munkák. Több muszlim uralkodó illetve kormányhivatalnokok is alapítottak könyvtárakat, amelyek müködését kegyadományokkal (waqf) segítették.

Az irániak könyvszeretete, fordítási munkákban tett több évszázados erőfeszítéseik az Abbászidák korában gyakoroltak először jelentős hatást az arabokra. Harún al-Rasid bagdadi kalifa (uralkodott: 786-809) udvarában jelentős fordítási és könyvgyüjtési erőfeszítéseket tettek az uralkodót körülvevő tudósok. ${ }^{32}$ Itt, Bagdadban alakult meg az első (szintén nem muszlim hagyományokra alapozott) tudományos- és képzőközpont is, a „Bölcsesség Háza” (Bajt al-Hikma), Abd Allah al-Mamún kalifa uralkodása (813-833) alatt. Ehhez az intézményhez kapcsolódott a muszlim világ első nyilvános könyvtára. Nagy és jelentős volt ez a könyvtár, számos, messze földről hozatott tudós dolgozott falai között. Egy bizonyos Georgiosz b. Gabriel készítette el jó néhány görög mü arab nyelvü fordítását. Amikor néhány évtized múlva al-Mu'tadid (uralkodott: 892-902) kalifa új palotát építtetett magának, ő sem feledkezett meg az olvasótermekről és a könyvgyüjteménye méltó elhelyezéséről. ${ }^{33}$ 993-ban Sabúr vezír alapított egy tízezer kötetes könyvtárat, amelyek között számos önéletírás is volt. ${ }^{34}$

1064-ben épült fel Bagdadban Nizám al-Mulk vezír szorgalmazására és támogatásával a róla elnevezett könyvtár- és tudományos központ, a Nizámíjja, amelyet egyes neveléstörténészek a középkori európai egyetemek előképének" tartanak. 1233-ban ugyanebben a városban Musztanszír, az utolsó előtti Abbászida kalifa (uralkodott: 1226-1242) a Tigris folyó partján palotájával együtt madraszát és könyvtárat is emelt. Egy 13. századi történetíró, Ibn Furát így írt erről a könyvgyüjteményről: „A Musztansziríjjában volt egy hatalmas könyvtár (dár al-kutub), telis-tele ritka tudományos könyvekkel, amelyeket úgy rendeztek el, hogy a tanárok és diákok egyaránt könnyedén hozzájuk férhessenek. Aki akarta, lemásolhatta a könyveket, tol-

31 BOSWORTH, E. - DONZEL, E. - LEWIS, B. - PELLAT, CH. (ed.): The Encyclopaedia of Islam. V. E. J. Brill, Leiden, 1986. „madrasa” címszó, 1125. o. Referenceworks.brillonline.com: https://bit.ly/3filYvc

32 MAZAHÉRI i. m., 181. o.

33 BOSWORTH és mások i. m., 1125. o.

34 ELISSÉEFF, V - NAUDOU, J. - WIET, G. - WOLFF, PH. (ed.): Historia de la humanidad. Las grandes civilizaciones medievales I. Planeta - Ed. Sudamericana, Barcelona - Buenos Aires, 1977. 492. o. Iberlibro.com: https://bit.ly/3csATm3 
lat, tintát és papírt a könyvtár adott hozzá. A könyvtár jól el volt látva lámpákkal és hozzá való olívaolajjal. A könyvtár személyzete ezenkívül jól hütött ivóvízzel szolgált az olvasóknak a nagy nyári melegben. A bejárati teremben (iván) állt egy nagy óra (szundúk asz-száát, az „órák doboza”, valamilyen klepszidra, vagyis vízóra lehetett), amely jelezte az olvasóknak a napi imaidőket." ${ }^{35}$ A kalifa fia és követője, Muataszim (uralkodott: 1242-1258) két könyvtárépületet is építtetett palotája kertjében.

A muszlim világ keleti felének másik nagy szellemi központjának számító Kairóban is számos könyvtáralapítás történt az évszázadok során. A 10. századot megelőző idők kairói könyvtárairól nem maradtak fenn adatok, a Fátimidák gyüjteményeiről viszont több forrás is szól. Régi-Kairóban Al-Aziz (uralkodott: 975-996) tudhatta magáénak a legszebb, 200 ezer bőrbe kötött és kötetlen müvet tartalmazó könyvtárat, ahol például - al-Makrízi feljegyzései szerint 1200 példányt őriztek al-Tabari történelemkönyvéből. A Fátimidák ügynökei az egész muszlim világot bejárták, hogy uralkodójuknak felhajtsák a legértékesebb kéziratokat, könyvritkaságokat. Szaláhaddín korában, a 12. században a világ egyik csodájaként emlegették ezt a könyvtárat (Khizánat al-kutub), és egyesek 1.600.000-re becsülték az ott levő kötetek számát. ${ }^{36}$ A Fátimida kor másik jeles kairói közkönyvtárát, a Tudás Házát (Dar al-Hikma) 1005-ben alapította alHakim bi-Amr Alláh. Itt mindenki szabadon másolhatott, olvashatott, és előadások is folytak csillagászatról, nyelvészetről, orvostudományról és természetesen a Koránról. Az itt dolgozó tudósoknak a kalifa magas ösztöndíjat folyósított, és a művelödéstörténészek szerint ezen intézmény a hellenisztikus oktatási- és tudománypártolási tradíciók folytatója volt, az alexandriai Muszeion késői „utóda”. ${ }^{37}$ Al-Makrízi leírása szerint 1012-ben rendeztek itt először nyilvános vizsgát és tudományos disputát, a kalifa jelenlétében.

Az iszlám más keleti városaiban is számos könyvtárról maradtak fenn feljegyzések. A Szászánidák uralkodása alatt például Nisápúr vagy Bokhara volt több tízezer kötetes könyvtárral rendelkező város, Mervben pedig 10, egyenként 12 ezer könyvet tartalmazó könyvtár volt ebben az időszakban. A bokharai gyüjteményt használta Ibn Szína (Avicenna), aki ezt írta életrajzában: „Egy napon engedélyt kértem, hogy beléphessek (Núh Ibn Manszúr emir) könyvtárába, hogy

35 Idézi: DÉVÉNYI - IVÁNYI i. m., 88. o.

36 MAZAHÉRI i. m., 184. old., DÉVÉNYI - IVÁNYI i. m., 89-90. o., BOSWORTH és mások i. m., 1125. o.

37 E témáról lásd. pl.: WALDEN, J. W. H.: The Universities of Ancient Greece. New York, 1919. 48-50. o. Archive.org: https://bit.ly/3ssoN1S 
tanulmányozzam a könyveket és elolvassam közülük az orvosi munkákat. Az emír nagy örömmel fogadta kérésemet. Beléptem egy sok szobából álló palotába, amelynek minden termében könyvekkel teli ládák sorakoztak - az egyik szobában bölcsészeti és költői müvek, egy másikban jogi könyvek, és valamennyiben egy-egy tudományt tárgyaló kötetek. Elolvastam az antik müvek katalógusát, és kikértem mindazt, amire szükségem volt belöle. A könyvek (szerzői) között láttam sok olyant, aki még névről sem volt ismerős, és akiket sem előtte, sem utána nem láttam."”38

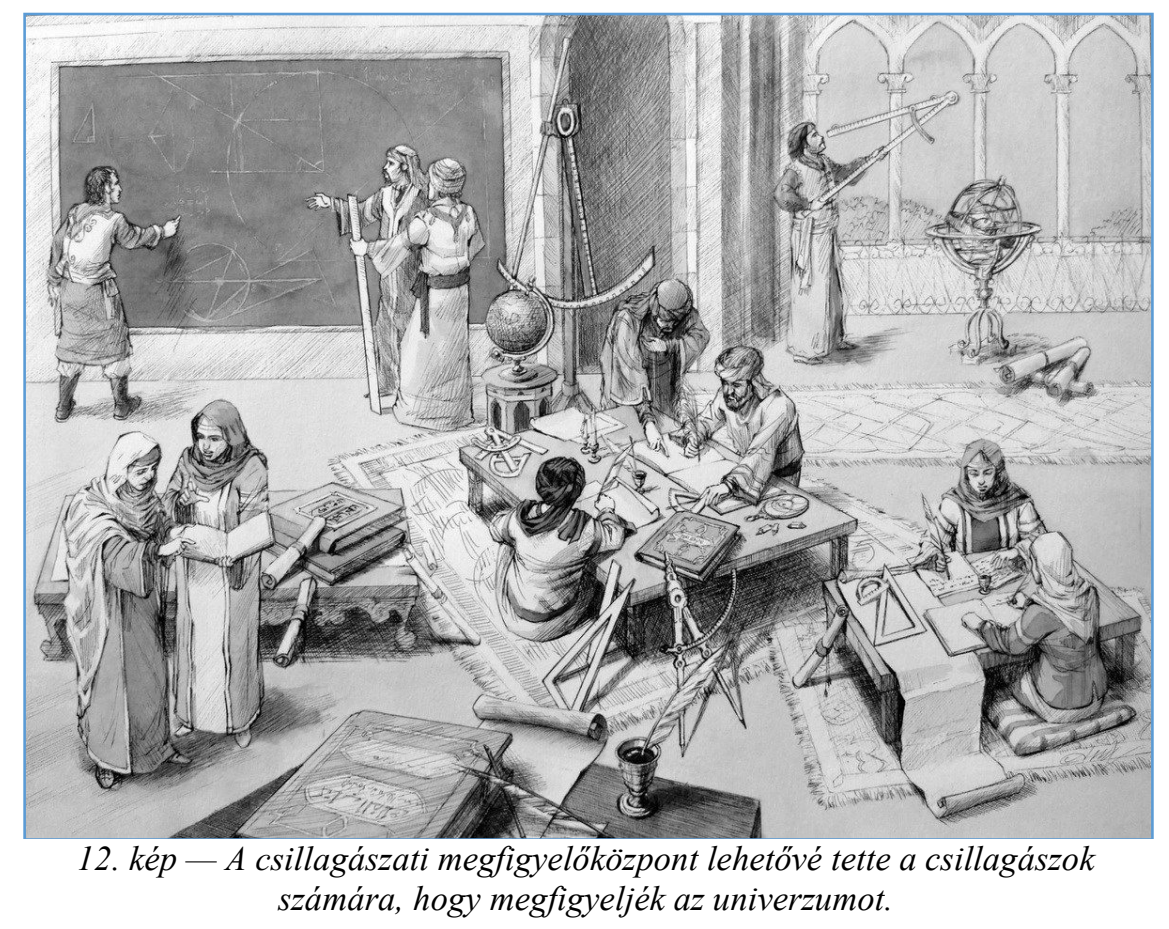

A fentebb felsorolt adatokból, az egykori szemtanúk leírásaiból is látszik, hogy az uralkodók és mecénások Bagdadban, Kairóban Bokharában és másutt is nagy hangsúlyt fektettek a tudományok, a tudósok támogatására, a diákok istápolására. Könyvtáraik köteteivel egyrészt saját tudásvágyukat szerették volna kielégíteni az alapítók, másrészt pedig tanuló és kutató emberek százainak és ezreinek mindennapi munkáját könnyítették meg a könyvgyüjteményekkel. A lehető legjobb módon szervezett és legkellemesebb körülményeket megte-

38 AVICENNE: Le livre de Science. Les Belles Lettres, UNESCO, Paris, 1986. 16. o. A forrásrészletet franciából fordította: Kéri Katalin. AbeBooks.fr: https://bit.ly/2PtWEsx 
remtő, papírt, tintát, világítóeszközöket ingyen nyújtó könyvtárak valódi szellemi központok voltak. A középkori iszlámra oly jellemző tudomány- és tanuláspártolás tehát a könyvtáralapítások és müködtetések számos példájával is alátámasztható.

\subsection{Könyvtárak al-Andalúszban}

A muszlimok a 8. század második évtizedében léptek az Ibériaifélsziget földjére, amikor Vitiza, gót király halála után párthívei összecsaptak fiának, Roderichnek a csapataival. Ez a század a déli nagyvárosokkal kötött paktumok időszaka volt, az arabok és berberek egyre jobban megvetették lábukat a térségben. I. Abd al-Rahman teremtette meg a hispániai Omajjáda-dinasztia alapjait, és utódai idején alakult ki az emirátus, majd a kalifátus, mely 929 és 1031 között állt fenn. ${ }^{39} \mathrm{~A}$ muszlimok nagyon kellemesnek találták a félsziget déli és középső területeit, egyikük azt írta a kalifátusról, hogy kellemes klímája és tiszta levegője révén a vidék Szíriára hasonlít; olyan, mint Jemen, ha hőmérsékletét tekintjük; átható illatai miatt Indiára emlékeztet; kincstári jövedelmeit tekintve olyan gazdag, mint a perzsiai Ahwaz; drágakövei Kínához teszik hasonlatossá, tengerparti termékei pedig Adenhez. ${ }^{40}$

Az Ibériai-félszigetre érkezők magukkal hozták Európába kultúrájuk azon elemeit is, amelyeket keleti hódításaik során építettek be civilizációjukba, és amelyek a 8. századtól kezdve fokozatosan alAndalúsz területén is elterjedtek. Így magukkal hozták a könyveket, az olvasás szeretetét. Híres másolóműhelyek sora (Córdoba, Sevilla, Toledo, Granada), papírmalmok (Toledo, Jatíva) és a fóbb városokban szinte mindenütt felhalmozott csodálatos könyvgyüjtemények jelzik az al-andalúsziaiak müveltségről, tanulásról vallott felfogását. Az arabizáció - a könyveknek is köszönhetően - gyorsan végbement, föként a felsőbb társadalmi rétegek körében. A Korán nyelve hamar felülkerekedett a latinon, az irodalmi és tudományos müvekben is. ${ }^{41}$

Keletről tehát számos könyvmásoló, fordító, tudós és tanár érkezett, akiknek jelenléte kétségkívül nagyban hozzájárult al-Andalúsz településeinek felemelkedéséhez. A minden muszlim számára kötelező mekkai zarándoklat is segítette a gondolatok és müvek Keletről Nyugatra és ellenkező irányban való áramlását, hiszen a vándorúton

39 VALDEÓN, J.: El califato de Córdoba. Cuadernos de Historia 16. 102. füzet, Madrid, 1985. 4. o. Issuu.com: https://bit.ly/3rtVytW

40 PERICOT, L. G. (dir.): Historia de España II. La alta edad media: siglos V al XIII. Instituto Gallach, Barcelona, 1970. 176. o.

41 ESCOLAR, H.: Historia de las bibliotecas. Fundación G. S. R., Madrid, 1987. 133. o. 
lévő férfiak (néha nők is) zarándoklataik során gyakran szenteltek hosszabb-rövidebb időt annak, hogy nagy hírủ tanítómestereket hallgassanak, hogy híres könyvtárakban és jó nevü könyvpiacokon forduljanak meg.

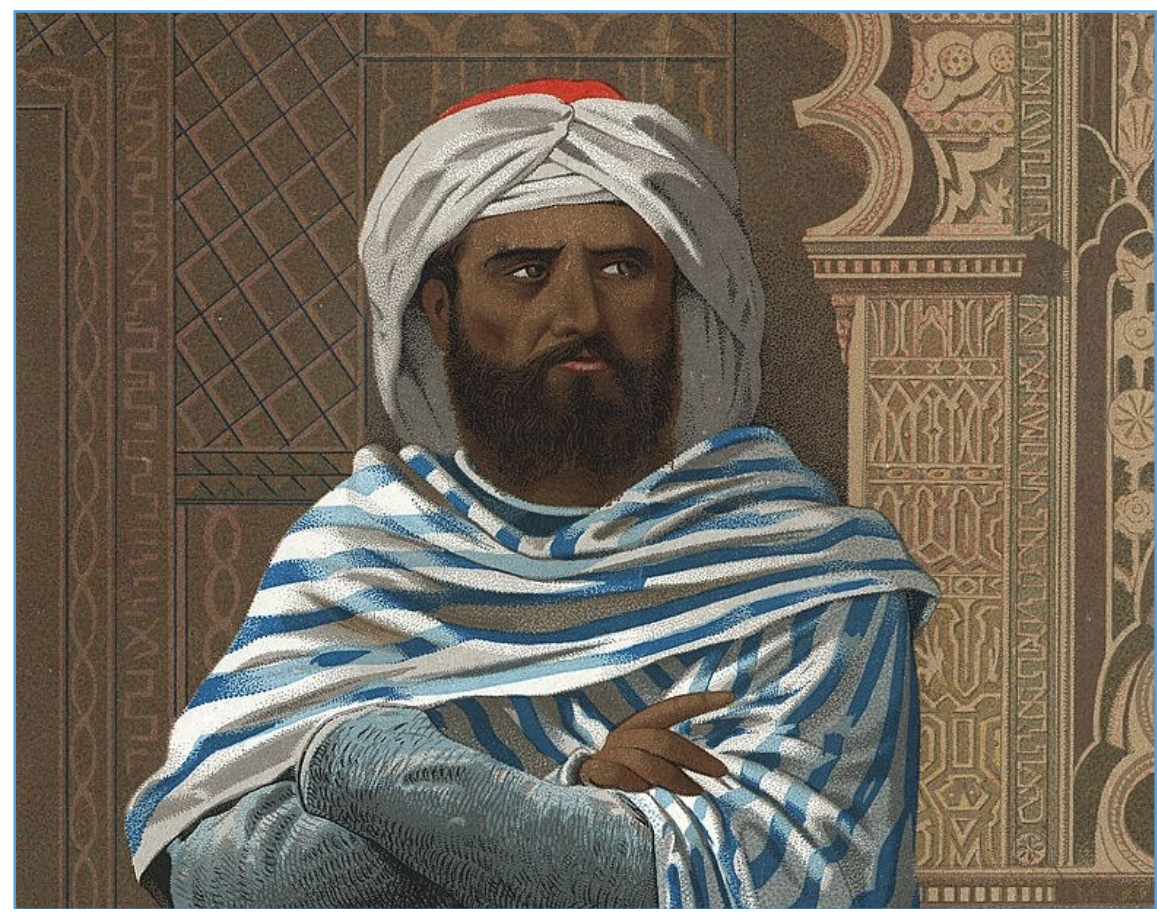

13. kép - I. Abd al-Rahman (731-788)

Az Omajjáda dinasztia több tagja is élénk érdeklődést mutatott a tudományok és a könyvek iránt. Az emírek és kalifák általában maguk is foglalkoztak különféle tudományokkal. Az algebra, a fizika, az orvostudomány, a filozófia, a csillagászat, a vallás- és jogtudomány, a botanika eredményeit az arab tudósok sok ezernyi könyvben foglalták össze, és jelentős fordítási munkákat is végeztek. Virágzott a költészet, a történetírás. Fellendült az iskolaalapítás, és az első andalúziai könyvtárakat is az Omajjádák állították.

II. Abd al-Rahmán, aki 821 és 852 között uralkodott, már az emirátus idején kiemelt figyelmet fordított a könyvekre, és asztrológusát, a költőként és kádiként is kiemelkedő hírü Abbász ibn Nászih-t Keletre küldte, hogy könyveket vásároljon számára. Utódja, II. Mohamed (852-886 között volt emír) királyi könyvtárat létesített, amely sok évtizeden át tovább bővült, és a 10. század végének híres cordo- 
bai könyvtárát II. al-Hakam ezzel alapozta meg.42 III. Abd alRahmánnak, az első kalifának könyvszeretete még Keleten is annyira közismert volt, hogy a bizánci császár - hogy elnyerje barátságát megajándékozta őt Dioszkoridész egy müvével, mely arany betükkel írott, csodás növényrajzokkal díszített volt; és egy Nikolaosz nevü szerzetest fordítónak küldött Córdobába. ${ }^{43}$

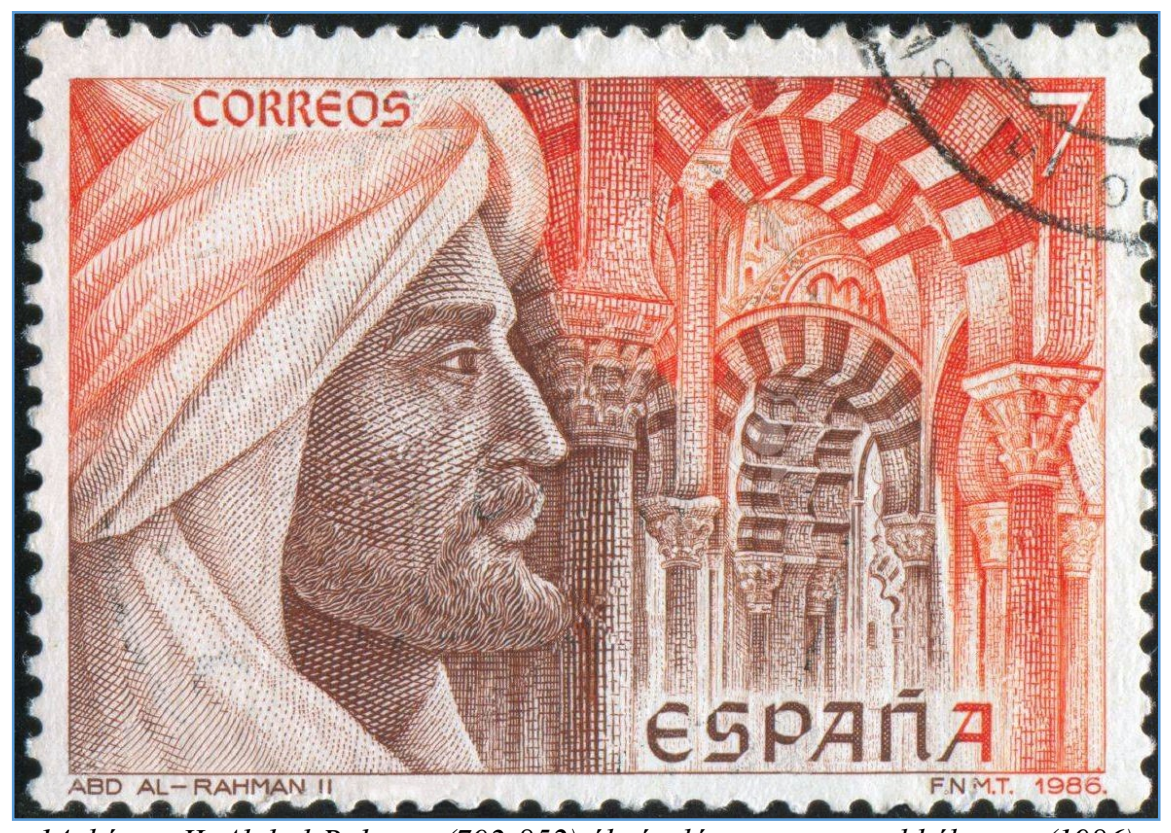

14. kép - II. Abd al-Rahman (792-852) ábrázolása egy spanyol bélyegen (1986)

Al-Hakám al-Musztanszír billah, aki 961 és 976 között volt kalifa, az andalúziai Omajjádák közül a legmüveltebb uralkodó volt, a „,könyvek ura". Mivel apjától pacifikált birodalmat örökölt, jutott ideje arra, hogy társadalmi és tudományos kérdésekkel foglalkozzon. Folytatta apja iskolapolitikáját, a szegények számára is oktatási intézményeket nyitott. Uralkodása időszakában a tanárok többsége közalkalmazott volt, a kalifától vagy diákjaik szüleitől nyerték fizetésüket. ${ }^{44} \mathrm{Al}-$ Hakám már gyermekként nagyon szerette a könyveket és a tudományokat, ami valószínüleg annak is köszönhető volt, hogy Córdoba legkiválóbb tudósai nevelték. Az apja által gyüjtött kötetek mellé ki-

42 SAMSÓ, J.: Ciencia musulmana en España. Cuadernos historia 16. 144. füzet, Madrid, 1985. 8. o. Issuu.com: https://bit.ly/31rc43m

43 CARLO, A. M.: Introducción a la historia del libro. Fondo de Cultura Económica, Mexico-Madrid, 1993. 249-250. o.

44 DAMSEAUX - SOLANA: Historia de la pedagogia. Escuela Española, Madrid, 1967. 107. o. Iberlibro.com: https://bit.ly/39niAwF 
végzett öccse könyveit is megörökölte. Míg a trónra lépésre várt (ötven éves koráig!), elsősorban a tanulásnak és olvasásnak szentelte idejét. Kiegyensúlyozott, higgadt és békeszerető ember volt, aki nem is nagyon szeretett kimozdulni palotájából és annak kertjéből. A kortársak szerint nagyobb örömmel töltötte el néhány tudós társasága vagy könyveinek lapozgatása, mint a hatalom, a csillogás, a háborúskodás. ${ }^{45}$

A kalifa uralkodása alatt a 3 legnagyobb córdobai könyvtárat egyesítették, és így létrejött az a csodálatosan gazdag intézmény, amely a korabeli leírások szerint 400 ezer kötetet számlált. (Ez több kutató szerint költői túlzás, ám a könyvtár jelentőségét senki nem vonja kétségbe.) A könyvtár vezetője egy eunuch volt, akinek feladata volt a könyvek őrzése és a katalógusok elkészítése. A könyvekről készült címjegyzék 44, egyenként 50 lapos füzetet tett ki. ${ }^{46} \mathrm{~A}$ palotában folyamatosan dolgoztak félsziget legjobb könyvkötői, szicíliai és bagdadi mesterekkel együtt, valamint könyvillusztrátorok, másolók hadai. Az elkészült könyveket egy tudományos bizottságnak mutatták be, melynek tagjai ellenőrizték és korrigálták a szöveget. A kalifa szolgálatában állt egy Talid nevü eunuch, aki a könyvkészítést felügyelte és vezette. Kalligráfusai között nők is akadtak, például két olyan kiváló hölgy (Fátima és Aisja), akik egész életüket a kalligráfiának szentelték, férjhez sem mentek.

II. al-Hakám volt a legkiemelkedőbb bibliofil személyiség, aki rendszeresen megbízottakat küldött az iszlám birodalom valamennyi szegletébe, hogy megvásárolják és elhozzák számára a legkiválóbb tudományos múveket. Al-Huszáni azt mondta a kalifáról, hogy tudósait arra ösztönözte, hogy gyüjtsék egybe a világban szétszórtan meglevő ismereteket, és szerezzék meg a pusztulás veszélyének kitett műveket, amelyeket korábban gondatlanul kezeltek. ${ }^{47}$ A kalifának telepített ügynökei voltak Kairóban, Damaszkuszban, Alexandriában és más kulturális központokban, ahol is új vagy éppen ősrégi könyvek után kutattak. Megbízottjai az írókkal is kapcsolatban állottak, az elkészült köteteket mesés összegekért vásárolták meg al-Hakam számára. Goldziher Ignác akadémiai székfoglalójában megemlítette például, hogy amikor egy iraki tudós egy müvén dolgozott (al-Iszfaháni arab költészetről és zenéről szóló átfogó gyüjteményéről van szó), a kalifa ezt meghallván ezer aranyat küldött neki azzal a feltétellel,

45 L. erröl: MOLINA, A. M.: Córdoba de los Omeyas. Planeta, Barcelona, 1994.

46 PERICOT i. m., 234. o. | Goldziher Ignác: Az iszlám kultúrája I-II. című művében, a spanyolországi muzulmánokról írott akadémiai székfoglalójában huszonnégy füzetet említett. Gondolat, Budapest, 1981. Antikvárium.hu: https://bit.ly/2QM6N11 | PTE OPAC - 930.8 G 50: https://bit.ly/3cq2sMC

47 VALDEÓN i. m., 28. o. 
hogy a könyv elkészülte után azonnal küldjön számára egy példányt, még mielött az Keleten ismeretessé válna. ${ }^{48}$

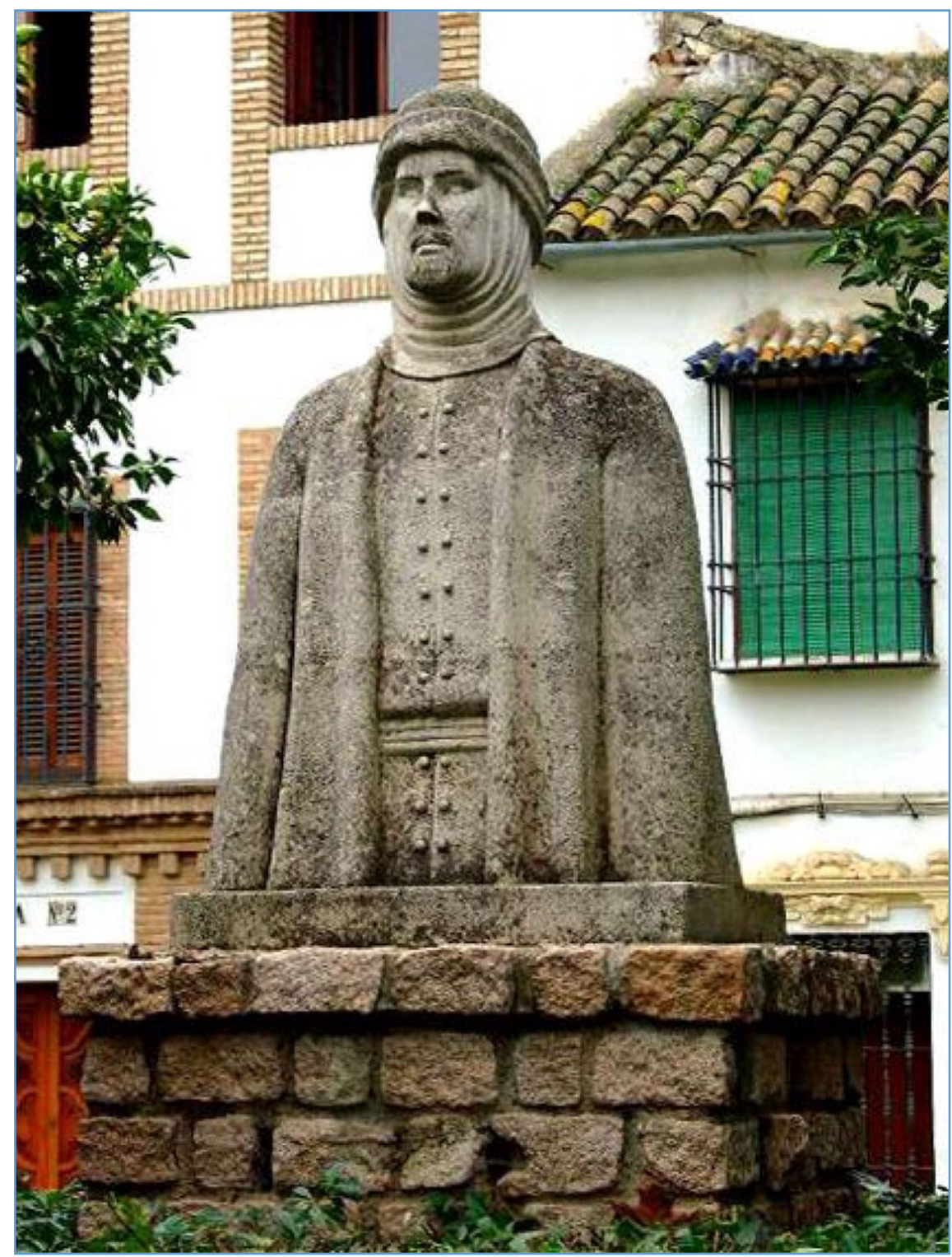

15. kép - II. Al-Hakám (915-976) szobra Cordobában (Pablo Yusti, 1973)

II. al-Hakám nem csupán egy megszállott könyvgyüjtő volt. Sok más neves elődjéhez hasonlóan, ő is sokat és értően olvasott. Olvasás közben a margóra írta észrevételeit, és mindig feljegyezte, hogy mikor fejezte be az olvasást, valamint azt, hogy ki a szerző és honnan

48 GOLDZIHER (1981) i. m., 142. o. 
származik. Mindent akart tudni, ezért igyekezett minél többet olvasni. Valószínűleg forgatta Ibn Rabbihi híres enciklopédiáját, az „Iqd alFarid" címü 25 kötetes munkát, mely mintegy tízezer oldalas tudományos gyüjtemény volt.

Az uralkodói alapítású és fenntartású könyvtárak mellett számos magánszemély is rendelkezett saját könyvgyüjteménnyel alAndalúszban. A córdobai magánkönyvtárak közül leghíresebb volt Ibn Futáisz kádi gyüjteménye, aki külön emeltetett imádott könyvei számára egy zöld tetővel és falakkal, zöldre festett függönyökkel felszerelt épületet. (Sevillai Isidorushoz hasonlóan ő is úgy vélte, ez a szín nyugtatja leginkább a megfáradt szemet.) Hat másoló és egy kéziratjavító dolgozott az épületben. Állandó fizetséget kaptak, nem pedig az elkészült munkák után fizették őket, mivel Ibn Futáisz úgy vélte, a sietség árt a kalligráfiai munka szépségének. Ez a kádi is - kalifájához hasonlóan - mindent megtett, hogy egy-egy könyvet megszerezzen, akár a kötet értékének három-négyszeresét is hajlandó volt kifizetni. Másolóit börtönőrként örizte, és semmilyen körülmények között nem volt hajlandó kölcsönadni egyetlen könyvét sem. ${ }^{49}$

A kalifátus idején tehát Córdoba volt az andalúziai szellemi központ, a könyvkészítés és könyvtáralapítás fellegvára. A források szerint évi 60-70 ezer kötet is napvilágot látott a „világ díszének” tartott csodás városban. A kis királyságokra szakadt birodalomban aztán több új szellemi központ is keletkezett, amelyeknek a története elválaszthatatlan könyvtáraik históriájától. Sevilla, Toledo, Almería, Valencia, Badajoz, Granada, Zaragoza és más települések uralkodói is létesítettek kisebb-nagyobb könyvtárakat. Az almeríai király egyik minisztere, Abu Dzsafár ben Abász például olyannyira bibliofil személyiség volt, hogy a könyvbeszerzés kapcsán találékonyságban még Ibn Futáiszon is túltett. Nem is annyira a könyvek szépsége érdekelte őt, mint inkább ritkaságuk és régiségük. Nem csak teljes példányokat, hanem egyes lapokat is megvásárolt, valamint öreg tekercseket és régi írószerszámokat. ${ }^{50}$ Sevillában az Abadiák, Granadában Beni alAhmár, Zaragozában Beni Hud, al-Moktadír, Valenciában Aben Saguir és mások szintén közismertek voltak könyvszeretetükröl a kalifátus széthullása után. ${ }^{51}$

49 ESCOLAR i. m., 136. o. és MOLINA i. m., 112. o.

50 ESCOLAR i. m., 136. o.

51 ESTEBAN, L. - MARTÍN, R. L.: Historia de la enseñanza y de la escuela. Tirant lo Blanch, Valencia, 1994. 76. o. Editorial.tirant.com: https://bit.ly/3m53m4A 


\subsection{A könyvtárak berendezése és müködtetése}

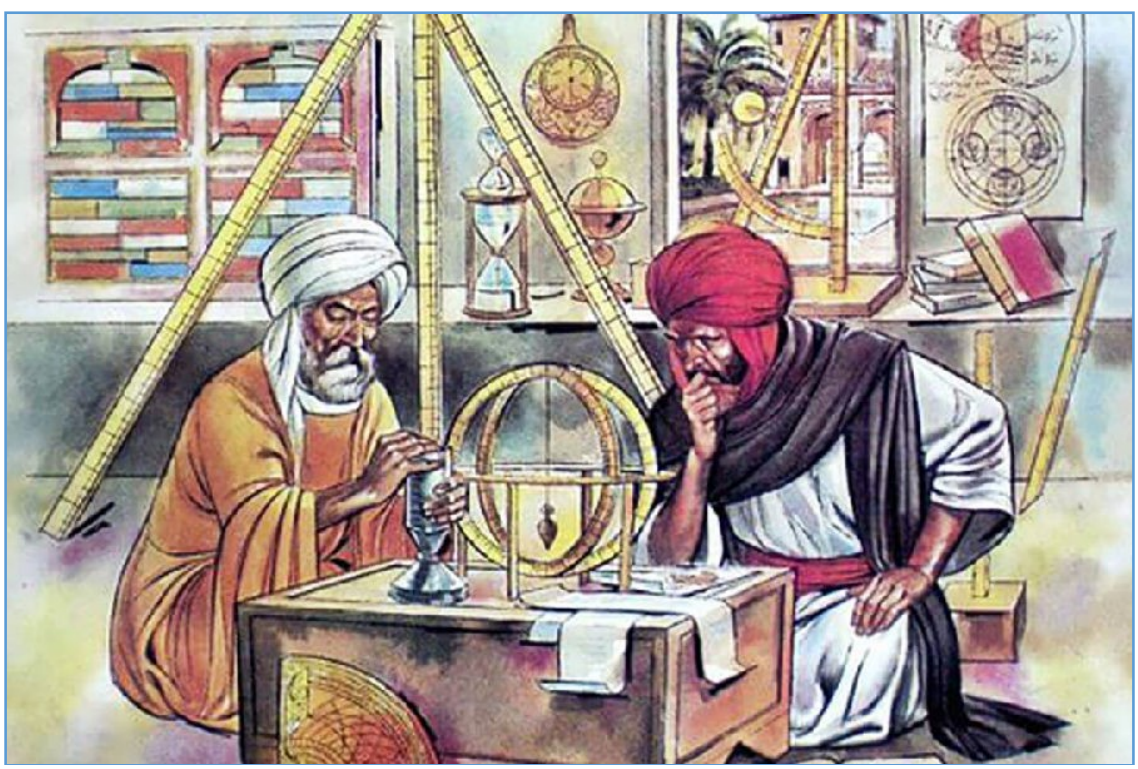

17. kép — Középkori muszlim tudósok

A fentiekben ismertetett nyilvános vagy magánkönyvtárak mindennapi működtetése meglehetősen komoly feladatot jelentett a megbízott személyzetnek. Hasonlóan, mint a nagy ókori könyvgyüjteményeket, a középkori iszlám könyvtárait is számos ember munkája tartotta életben. A könyvtár vezetőjén kívül a külön e célra kialakított épületekben dolgoztak a kisegítők, a könyvmásolók, a könyvkötők, a korrektorok és gyakran a fordítók is. A közkönyvtárak köteteinek használói között több volt a másoló, mint az olvasó; emiatt biztosították az emírek és kalifák az ingyen tintát és papírt is a fenntartásuk alá tartozó intézményekben. Valószínüleg a könyvtári funkciók elemi szintjével magyarázható, hogy a középkori iszlám világában nem jött létre egy, speciálisan könyvtárépítésre alkalmazott építészeti megoldás. A könyvtár vagy a mecseten belül volt, vagy az uralkodói palotában, ez utóbbi legszebb, legtágasabb termében. Ha külön helyiség(ek)ben tartották a könyveket, akkor azok raktárak és olvasótermek is voltak egyben, sőt, tudományos viták lefolytatására szolgáló termek is. ${ }^{52} \mathrm{Az}$ ajtórések függönnyel záródtak, a talajon szőnyegeket (vagy gyékényt) helyeztek el. A falakat általában egyszerüen lemeszelték, és a falnak támasztva tartották a fából készült szekrényeket vagy ládákat. Az értékes könyveket (pl. a Korán egy-egy remekbe

52 ESCOLAR i. m., 138. o. 
szabott példányát) - miként gyakorta manapság is - kiemelték a helyükről, és speciális vitrinekben állították ki. Minden szekrényhez vagy ládához tartozott egy katalóguslap, amelyre rávezették, hogy milyen könyvek találhatóak benne. A nagyobb könyvtárakban rendezöelvként próbálták figyelembe venni a könyvek témáját, és egy helyre tették az azonos tudományághoz vagy ugyanahhoz a szerzőhöz tartozó műveket. Ez azonban kicsit nehézkes volt mindenütt, mert a könyvek sokféle mérete bonyolította az észszerü pakolást. Külön rekeszekben, fekvő helyzetben gyüjtötték például a nagyobb méretü köteteket. A szekrények és polcok elrendezésénél azt is figyelembe vették, hogy a tudományok hierarchiáját alapul véve melyik mü a fontosabb. Mindig a legértékesebb müvek voltak felül. Így például a Korán mindig legfelül volt, és csakis alatta helyezkedhetett el a hadísz szövege.

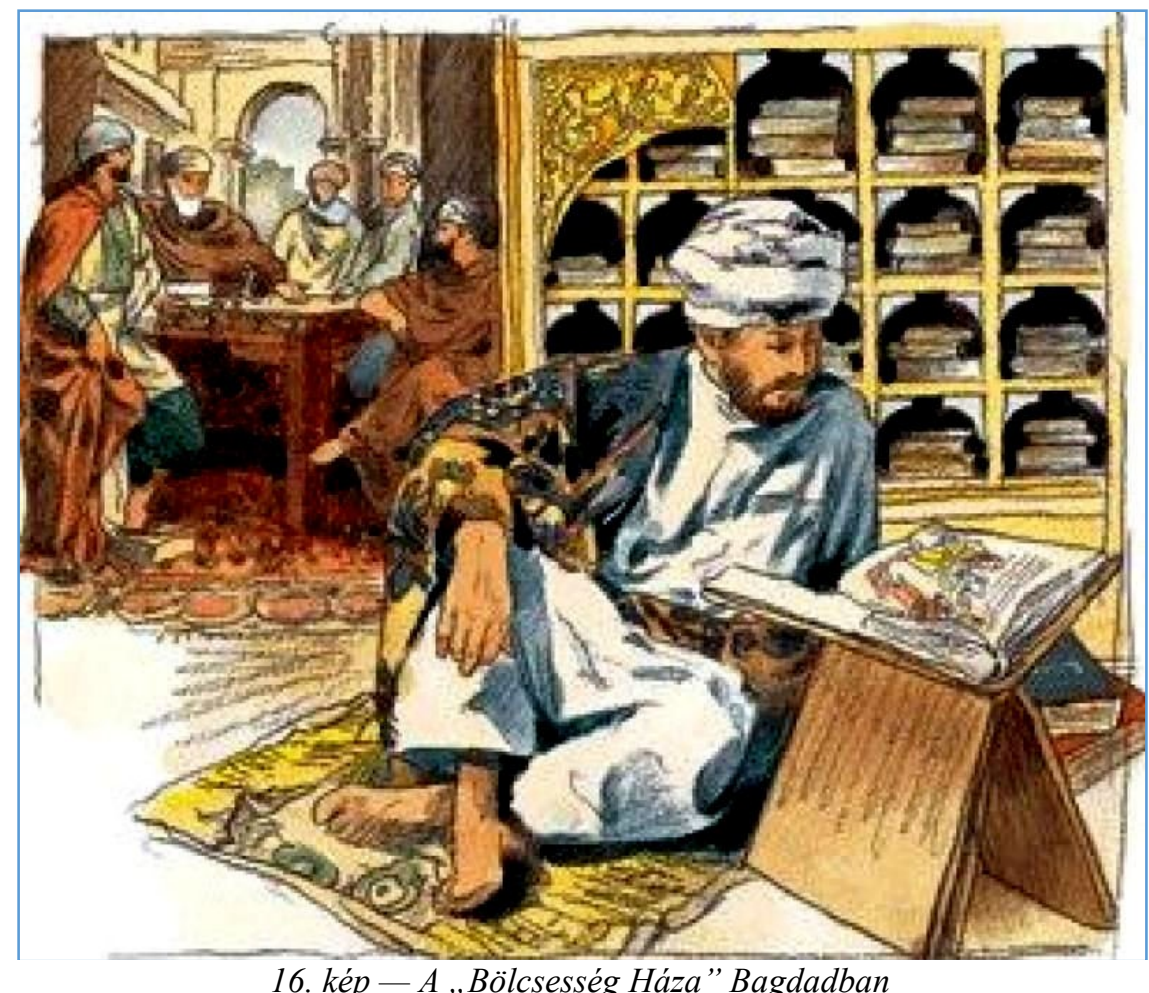

A téma szerinti osztályozás általában a könyvek három főbb csoportra bontását jelentette: az elsőbe tartoztak a legfontosabb, és éppen ezért mindig legnagyobb példányszámú vallásos művek (a Korán, a hadísz, valamint müvek a vallásjog, a dogmatika és a misztika köréböl). A második csoportba tartozó könyvek felölelték a bölcsészeti tudományokat (filológia, grammatika, retorika, logika, költészet, történelem, iroda- 
lom stb.), a harmadik nagy együttest pedig a „filozófiai” tudományok jelentették (matematika, orvoslás, fizika, zene, metafizika stb.). ${ }^{53}$

A könyvtár vezetője általában olyan férfi volt, aki jól ismerte a könyvek java részét, és akiben a könyvek tulajdonosa maradéktalanul megbízott. Legfőbb feladata a könyvek őrzése volt, a kéziratok védelme a tolvajoktól, a nedvességtől, a kártékony rovaroktól és a tüztől, de öt terhelte a felelősség amiatt is, hogy a könyvmásolás rendben és minél inkább hiba nélkül menjen végbe. Ha a könyvtár kölcsönzött is, az igazgatónak kellett megtenni a szükséges lépéseket a könyvállomány megóvása kapcsán.

A könyvtárak fenntartása nem volt mindig zökkenőmentes. Újra meg újra jelentős összegeket kellett költeni Bagdadtól Córdobáig a müködtetésre. Al-Makrízi például, beszámolva Hákim kalifa kairói könyvtáráról, leírta, hogy az évi 257 dinárból ,jut az abadáni gyékényre és a hozzá hasonlókra 10 dinár, továbbá írás és másolás céljára papírra 90 dinár, könyvtárlókra 48 dinár, a felhasznált vízért 12 dinár, a könyvtárszolgáknak 15 dinár, a felügyelö vallástudók számára tinta 15 dinár, a felügyelő fakíhok (vallási emberek) számára tinta, papír és toll 12 dinár, a függönyök megjavítására 1 dinár, könyvek borítóinak vagy papíranyagának helyrehozatalára 12 dinár, téli takaróra 5 dinár, télen szőnyegekre 4 dinár, és így tovább." ${ }^{54}$ Egyébként a könyvadományozás vagy a könyvtáraknak tett felajánlások is ájtatos cselekedetnek számítottak az iszlám világában, és arra is több példát lehet hozni, hogy a diákok, a szegények - az ingyenes belépésen kívül - különböző (fentebb már említett) jótéteményekben, ellátásban részesültek az uralkodói könyvtárakban. Valószínűleg széles körben ismert és fennen hirdetett volt az a hagyomány, amely mások segítésére késztette a moszlimokat: „Egy muszlim nem tud semmi jobbat ajándékozni testvérének, mint a bölcsesség egy szavát, ha Allah csak egy bölcs ember felé vezérli az utadat, jobb az teneked, mint az egész világ." 55

\subsection{A középkori muszlim könyvtárak sorsa}

Az iszlám művelődés korai történetét áttekintve világosan látszik, hogy e kultúrkörön belül is megvolt a könyveknek és a könyvtáraknak a saját sorsuk. Mégpedig - amint az a kisebb és nagyobb, a nyilvános és magánkönyvtárak iszonyú pusztulásáról szóló sorozatos be-

53 ESCOLAR i. m., 140. o.

54 Idézi: DÉVÉNYI - IVÁNYI i. m., 91. o.

55 IBN DZSÁIR-t idézi: CHEJNE, A. G.: Historia de España musulmana. Catedra, Madrid, 1993. 159. o. 
számolók alapján kitủnik - szomorú sors. Mivel a muszlim világ keleti és nyugati felében egyaránt jellemző volt a gyakori uralkodó- illetve dinasztiaváltás, mivel egymást érték a belharcok, a vallási irányzatokkal, vallásjogi iskolákkal összefüggő csatározások, mivel folyamatos politikai, hatalmi villongásoknak lehetünk tanúi az évszázadok forrásait megidézve, nem váratlan és nem érthetetlen a könyvtárak pusztulásáról, széthordásáról vagy kiárusításáról szóló számos híradás. Mindenekelőtt ki kell emelnünk, hogy az iszlám könyvtárainak pusztítói legtöbb esetben maguk a muszlimok voltak. Ugyan találhatunk példát mongolok, keresztények és mások által végrehajtott könyvpusztításokra is, de gyakoribb az olyan feljegyzések száma, melyek arról tanúskodnak, hogy egy-egy, hatalomra kerülő irányzat - üldözendő megdöntött elődei vallási-politikai (eretnek!) nézeteit - döntött egy adott könyvtár részleges vagy teljes megsemmisítéséről. Ez történt például az al-Hakám-féle mesés córdobai könyvtár esetében.

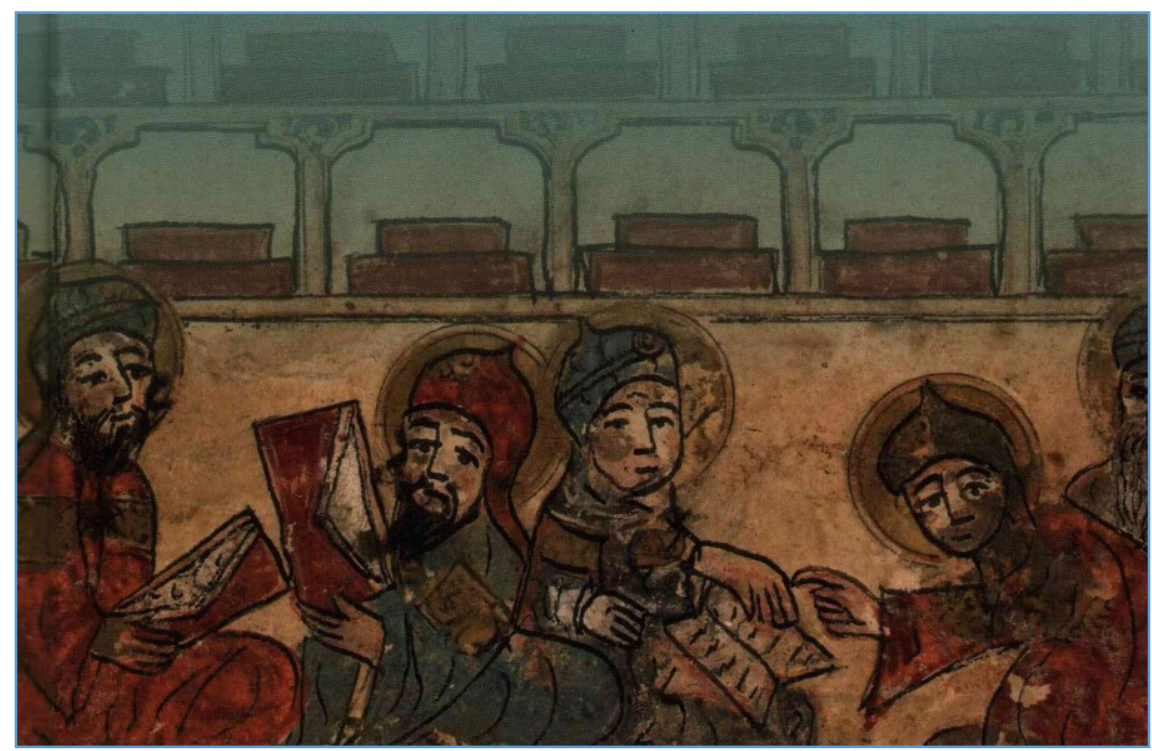

18. kép — A középkori Damaszkusz

(az Ashrafìya könyvtár katalógusának boritóképe)

A kalifa utódja, II. Hiszám (uralkodott: 976-1009) kénytelen volt átengedni a hatalmat al-Manszúrnak, aki jelentős hódításokba kezdett, és nem nagyon érdekelték a könyvek és a tudományok, felhagyott a toleranciával, és üldözte a tudósokat. Az ortodox nézetek kerültek elötérbe, és II. al-Hakám nagyszerü tudományos könyvgyüjteményét - Abu Amir Mohamed ben Abi Amir kamarás vezetésével - feldúlták, szét- 
szórták, elégették és a palota kútjába dobálták. ${ }^{56}$ Szaíd, a 11. században élt történész, toledói kádi korabeli leírása szerint mindez a következő módon zajlott: „(A kamarás) ..., alighogy a kormány megbízta, elment a kalifa apjának, al-Hakámnak a könyvtárába, ahol ott voltak a már említett könyvek és még sok egyéb holmi. A vezető vallástudósok jelenlétében kihordatott minden müvet, amit ott talált, és elrendelte a régi - logikáról, asztrológiáról és más antik - tudományokról szóló könyvek kiválogatását (kivéve az orvosi és matematikai könyveket). Oly módon (történt a kiválogatás), hogy mikor ezek elkülönültek a grammatikától, költészettől, történelemtől, orvoslástól, prófétai hagyományoktól és más tudományos müvektől, melyeket az andalúziaiak készítettek, elrendelte, hogy a megmaradt könyveket kivéve - mely a kisebb hányadot tette ki - az összeset el kell pusztítani és égetni. Egyesek tüzre kerültek, a többit a palota kútjába dobálták és földdel meg kövekkel betemették." ${ }^{7}$ Ezt követően is ezerszám hajigálták máglyára a córdobai könyvtár „eretnek-gyanús” köteteit, és a tüz attól kezdve már sosem hamvadt el. A 11. században, a palota többszöri kifosztása során a máglyától megmenekült könyveket széthordták; könyvpiacokon, gyakran papír-áron keltek el. Ez lett a sorsa több magánkönyvtárnak is, például az al-Futáisz által egykor féltve őrzött gyüjteménynek, amelytöl tönkrement örökösei csekély pénzért váltak meg. Az andalúziai könyvtárak tehát nem semmisültek meg teljesen, valenciai, almeríai, toledói és más bibliofilek hozzájutottak bizonyos példányokhoz. Aztán 5 évszázaddal később, Granada visszafoglalása után Cisneros kardinális elrendelte, hogy égessék el nyilvánosan a megmaradt muszlim könyveket. A katolikus spanyolok a középkor során, a nagy inkvizíciók idején sosem szüntek meg gyanakodni arab írást látván, félve, hogy hamisság és sátáni varázslat áll a számukra érthetetlen írásokban. Ribera y Tarragó, a neves spanyol iszlám-kutató kutatásai során például feljegyezte azt, hogy talált egy régi arab kéziratos könyvet a valenciai egyetemi könyvtárban, amelynek margóján az alábbi katalán jegyzet áll: „Ezt a könyvet én, Jaime Ferrán találtam, Laguar falujában, miután a mórok felmentek a hegyekbe, és mivel arab betükkel írott a könyv, sosem találtam olyan személyt, aki el tudta volna olvasni. Félek, nehogy Mohamed Korán-

56 BRENTJES, B.: Izmael fiai - Az arabok története és kultúrája. Kossuth, Budapest, 1986. 86. o. Antikvarium.hu: https://bit.ly/39jB5Cb | PTE OPAC — 930 B 88: https://bit.ly/31qv0iM

57 SZAID: Tabaqat al-Uman. Spanyolra fordította: Machado, O. A., spanyolból magyarra fordította: Kéri, K. In: SÁNCHEZ-ALBORNOZ, C.: La España musulmana I. Espasa-Calpe, Madrid, 1978. 417. o. Iberlibro.com: https://bit.ly/3ruomTa 
ja legyen ez..." ${ }^{98} \mathrm{E}$ nagy félelmet kiváltó mủ egyébként egy ártatlan nyelvtankönyv volt.

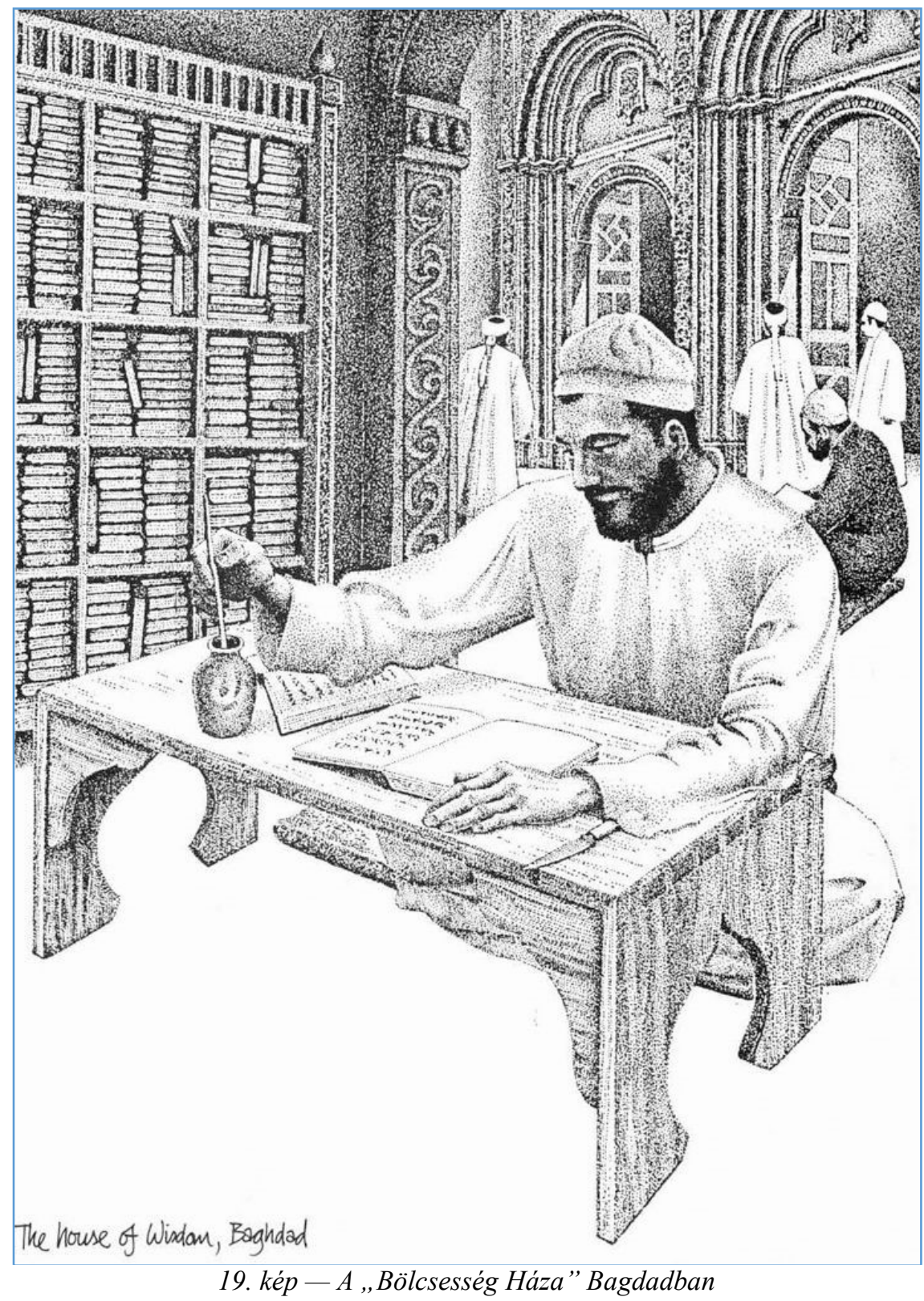

Találhatunk arra is példát, amikor egy-egy zürzavaros, nyomorúságos időszakban az elkeseredett tömegek dühének esett áldozatul valamely könyvtár. Kairóban például a 12. század elején számos könyv azért

58 MOLINA i. m., 124. o. 
semmisült meg, mert a fosztogatók a bör könyvborítókból szandálokat csináltak maguknak, a könyvlapokat pedig - mint számukra értéktelen holmit - eltüzelték vagy a Nílusba dobálták. ${ }^{59}$

A korabeli szemtanúk leírásán kívül tehát általában csak igen kevés maradt az egykori fényes könyvtárakból. Néhány kivételes értékü és ritka szépségü könyv természetesen ma is megcsodálható a párizsi, Escorial-beli, kairói, fezi vagy egyéb könyvtárakban és múzeumokban. Néhány hírmondóként maradt példány mindössze, melyek gondolatban elröpítenek minket a középkori iszlám kulturális centrumaiba. Ha csak igen töredékesen is, de bepillantást nyerhetünk az akkori gondolkodás, tudományos és kulturális élet kulisszái mögé. Az effajta vizsgálódások azonban nemcsak a muszlim világ megismeréséhez visznek közelebb. Az iszlám írásművészete, könyv- és könyvtártörténete tanulmányozása nagyon fontos az európai mủvelődéstörténet feltárása kapcsán is. A középkori Európa szellemi élete, a keresztény tudósok müveinek megértése ugyanis csak így lehet teljes. A 17. században élt jeles erdélyi gondolkodónk, Apáczai Csere János - aki egyébként a héber, görög és latin nyelv elsajátítása mellett negyedik idegen nyelvként fontosnak tartotta az arabot is - „néma mesterek”-nek nevezte a könyveket. Valószínủleg sok muszlim uralkodó, tudós, diák, könyvmásoló és fordító vélekedett hasonlóan, akik ezerszám készítették és olvasták a különböző müveket a mecsetek vagy könyvtárak falai között. Sokan voltak, akik nappal és éjjel pergamen, papirusz vagy papír fölé görnyedve, végeláthatatlanul rótták a betük sorát, hogy a tudást megőrizzék és átmenekítsék az elkövetkezendő nemzedékeknek. Ök tudták, hogy nincs nagyszerübb tájék a földkerekségen, mint az írott szó csendes birodalma.

\section{A képek jegyzéke és a jegyzetek}

\section{A képek jegyzéke}

1. kép: Korán: https://bit.ly/3dgZFEZ | Direkt link a forrásképre: https://bit.ly/2P45elt

2. kép: The House of Wisdom: Baghdad's Intellectual Power-house: https://bit.ly/3lUFCA2 | Direkt link a forrásképre: https://bit.ly/3db9Hat

3. kép: The round city of Baghdad in the 10th century, the peak of the Abbasid Caliphate. Illustration: Jean Soutif/Science Pho-to Library: https://bit.ly/3w4Z7dP | Direkt link a forrásképre: https://bit.ly/3m5cbve

59 ELLISSÉEFF és mások, i. m. 491-492. o. 
4. kép: Civilización del Islam: Los orígenes de la caligrafía islámica: https://bit.ly/3w4ocFA | Direkt link a forrásképre: https://bit.ly/3dauD1s

5. kép: Why is calligraphy so important to Islam? https://bit.ly/2NX52jO | Direkt link a forrásképre: https://bit.ly/3tTtySe

6. kép: Panel of Four Calligraphic Tiles 14th-early 15th century: https://bit.ly/3wfvM0q | Direkt link a forrás-képre: https://bit.ly/31VtOgZ

7. kép: When philosophy needed Muslims, Jews and Christians alike: https://bit.ly/3m1tihh | Direkt link a forrásképre: https://bit.ly/31oMzjl

8. kép: Muslim Inventions that Shaped the Modern World | Debunking The Golden Age Of Islam: Why 1001 In-ventions Exhibition Is An Exercise in Cultural Propaganda: https://bit.ly/31CPMvX | Direkt link a forrásképre: https://bit.ly/3tUlWPi

9. kép: The House of Wisdom: Baghdad's Intellectual Power-house: https://bit.ly/3dbxRSi | Direkt link a forrásképre: https://bit.ly/31rugKd

10. kép: Detail from 'The Meeting of the Theologians' by Abd Allah Musawwir, mid-16th century. Courtesy Wikipedia: https://bit.ly/39nMkt4 | Direkt link a forrásképre: https://bit.ly/3ctP8XS

11. kép: Ibn Rushd in his darkest hour: https://bit.ly/3dg8G0X | Direkt link a forrásképre: https://bit.ly/2PwPvaU

12. kép: Bayt al Hikmah Is Proof That Islam and Science Are Not, and Were Never, Contradictory: https://bit.ly/3w1RYuK | Direkt link a forrásképre: https://bit.ly/31qAWZ6

13. kép: Abd al-Rahman I. https://bit.ly/2QL2Ay3 | Direkt link a forrásképre: https://bit.ly/3w40JUZ

14. kép: ESPAÑA - CIRCA 1986: sello impreso por España, muestra Retrato de Abd Al Rahman II, alrededor del año 1986:

https://bit.ly/2PAgimy | Direkt link a forrásképre: https://bit.ly/2NXtAZZ

15. kép: II. Al-Hakam biography (915-976): https://bit.ly/3m8U0F3 | Direkt link a forrásképre: https://bit.ly/3d7RuKW

16. kép: La Nostalgie comme chemin de protection: https://bit.ly/2NXaaEA | Direkt link a forrásképre: https://bit.ly/31ZesI1

17. kép: Sina, Ghazali and Ar-Razi: who were they? https://bit.ly/391k3n5 | Direkt link a forrásképre: https://bit.ly/31Yh5tQ

18. kép: Medieval Damascus: Plurality and Diversity in an Arabic Library: The Ashrafiya Library Catalogue By: Hirschler, Konrad https://amzn.to/3tXf9Va | Direkt link a forrásképre: https://bit.ly/31rynpD

19. kép: The House of Wisdom, Baghdad: https://bit.ly/3u13Zio | Direkt link a forrásképre: https://bit.ly/3svq34j

20. kép: Scroll smugglers: How Timbuktu's secret treasures were saved: https://bit.ly/3rsZ6wS | Direkt link a forrásképre: https://bit.ly/3rsXHX1 


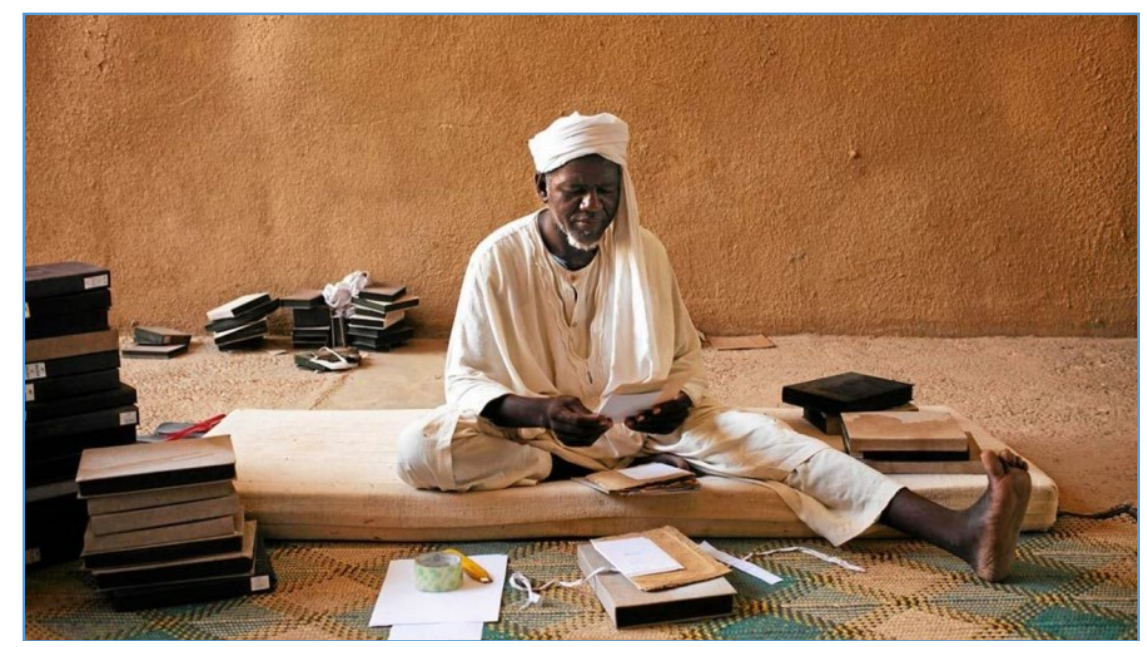

20. kép - Egy tudós a 13. századból származó teológiai kéziratokat olvas a timbuktui Ahmed Baba Iszlám Központban. (Reuters, 2012)

\section{Jegyzetek}

1. ARMSTRONG, K.: Mohamed. Az iszlám nyugati szemmel. Európa, Budapest, 1998. 78-80. o. Antikvarium.hu: https://bit.ly/3snLAvD | PTE OPAC - 290.6 A 83: https://bit.ly/3ct2zY4

2. SIMON, R.: Korán - A Korán világa. Helikon, Budapest, 1994. 422423. o. Antikvarium.hu: https://bit.ly/3rq7b59 | PTE OPAC — $290.6 \mathrm{~K}$ 70: https://bit.ly/3fijKNw

3. SIMON, R.: Korán - A Korán világa. Helikon, Budapest, 1994. 455. o. Antik-varium.hu: https://bit.ly/3rq7b59 | PTE OPAC - 290.6 K 70: https://bit.ly/3fijKNw

4. Részletesebben lásd: ROGERS, M.: A hódító iszlám. Helikon, Budapest, 1987. 23-25. o. Antikvarium.hu: https://bit.ly/3w6wMni | PTE OPAC - $290 \mathrm{G} 47$ : https://bit.ly/3w4lEaF

5. ROGERS, M.: A hódító iszlám. Helikon, Budapest, 1987. 31-31. o. Antikvari-um.hu: https://bit.ly/3w6wMni | PTE OPAC - 290 G 47: https://bit.ly/3w4lEaF

6. GLASENAPP, H.: Az öt világvallás. Gondolat, Budapest, 1987. 410411. o. Antikvarium.hu: https://bit.ly/31qK4Nj | PTE OPAC - 290 G 47: https://bit.ly/3w4lEaF

7. Lásd erröl: SIMON R. i. m. 460-476. o. Antikvarium.hu: https://bit.ly/3rq7b59 | PTE OPAC — 290.6 K 70: https://bit.ly/3fijKNw

8. Lásd erről: KÉRI, K.: Rendszer és tudás. Iskolakultúra (ISSN 12155233), VII. évf., 1997/október, 10. sz., 110-114. o. PTE PEA: https://bit.ly/3dfuiKT Keri-katalin.wordpress.com: https://bit.ly/3u09LR4

9. Korán, 2, 269. 
10. IBN KHALDÚN: Bevezetés a történelembe. Osiris, Budapest, 1995. 414. o. Antikvarium.hu: https://bit.ly/39jhstT | PTE OPAC - $930 \mathrm{~K}$ 44: https://bit.ly/3tRdVea

11. DÉVÉNYI, K. - IVÁNYI, T.: Az arab írás története. Kőrösi Csoma Társaság Keleti Nyelvek Kollégiuma, Budapest, 1987. 19. o. Antikvarium.hu: https://bit.ly/3u031Bz

12. Uott, 187. o.

13. MOLINA, M. A.: Córdoba de los Omeyas. Planeta, Barcelona, 1994. 114. o. AbeBooks.co.uk: https://bit.ly/3u2XIT1

14. MOLINA, M. A.: Córdoba de los Omeyas. Planeta, Barcelona, 1994. 115. o. AbeBooks.co.uk: https://bit.ly/3u2XIT1

15. TEVAN, A.: A könyv évezredes útja. Gondolat, Budapest, 1984. 53. o. Antik-varium.hu: https://bit.ly/2NYxsdn | PTE OPAC — 002 T 48: https://bit.ly/3suZrjF

16. Idézi: DÉVÉNYI-IVÁNYI i. m. 67. o.

17. MOLINA i. m. 116. o.

18. Idézi: DÉVÉNYI-IVÁNYI i. m., 55. o.

19. Az Ezeregyéjszaka meséi. Európa, Budapest, 1974. Fordította: Honti Rezső, 11. o. Antikvarium.hu: https://bit.ly/31vdxFP | PTE OPAC — E 99: https://bit.ly/31onTHF

20. A teherhordó és a három leány története. Fordította: Vajkay Lajos, i. m. Ezer-egyéjszaka meséi Uott., 39. o.

21. DÉVÉNYI- IVÁNYI i. m., 68. o.

22. MAZAHÉRI, A.: A muszlimok mindennapi élete a középkorban a 10től a 13. századig. Európa, Budapest, 1989. 187. o. Antikvarium.hu: https://bit.ly/2QAq6NY | PTE OPAC - 930.8 M 49: https://bit.ly/3919h0a

23. Művelt muzulmán nőkről lásd: KÉRI, K.: Nők a fátyol mögött. Valóság (ISSN 0324-7228), XLI. évf., 1998/augusztus, 8. sz., 64-70. o. PTE PEA: https://bit.ly/3crZOpA | Kerikatalin.wordpress.com: https://bit.ly/2QIFvvU

24. HITTI, P. K.: History of the Arabs. MacMillan, London, 1960. 414. o. Archive.org: https://bit.ly/2PyRziC

25. DODGE, B.: Muslim Education in Medieval Times. The Middle East Institute, Washington, 1962. 14. o. AbeBooks.com: https://bit.ly/3fwGzgT

26. MAZAHÉRI i. m. 188. o.

27. DÉVÉNYI - IVÁNYI i. m., 84. o.

28. GOLDZIHER, I.: Az iszlám. Magvető, Budapest, 1980. 384-385. o. Antikvari-um.hu: https://bit.ly/31opflJ | PTE OPAC — 290.6 G 50: https://bit.ly/3tRiDbQ

29. BEN SAID: Maghreb. Spanyolra fordította Ribera y Tarragó, J., spanyolból magyarra fordította Kéri, K. In: SÁNCHEZ-ALBORNOZ, C.: La España mu-sulmana I. Espasa-Calpe, Madrid, 1978. 415-416. o. AbeBooks.com: https://bit.ly/2PwBPwK 
30. TRITTON, A. S.: Materials on Muslim Education in the Middle Ages. Luzac and Co. Ltd., London, 1957. 195. o. Worldcat.org: https://bit.ly/3cpEelE

31. BOSWORTH, E. - DONZEL, E. - LEWIS, B. - PELLAT, CH. (ed.): The Encyc-lopaedia of Islam. V. E. J. Brill, Leiden, 1986. „madrasa” címszó, 1125. o. Re-ferenceworks.brillonline.com: https://bit.ly/3filYvc

32. MAZAHÉRI i. m., 181. o.

33. BOSWORTH és mások i. m., 1125. o.

34. ELISSÉEFF, V - NAUDOU, J. - WIET, G. - WOLFF, PH. (ed.): Historia de la humanidad. Las grandes civilizaciones medievales I. Planeta Ed. Sudameri-cana, Barcelona - Buenos Aires, 1977. 492. o. Iberlibro.com: https://bit.ly/3csATm3

35. Idézi: DÉVÉNYI - IVÁNYI i. m., 88. o.

36. MAZAHÉRI i. m., 184. old., DÉVÉNYI - IVÁNYI i. m., 89-90. o., BOSWORTH és mások i. m., 1125. o.

37. E témáról lásd. pl.: WALDEN, J. W. H.: The Universities of Ancient Greece. New York, 1919. 48-50. o. Archive.org: https://bit.ly/3ssoN1S

38. AVICENNE: Le livre de Science. Les Belles Lettres, UNESCO, Paris, 1986. 16. o. A forrásrészletet franciából fordította: Kéri Katalin. AbeBooks.fr: https://bit.ly/2PtWEsx

39. VALDEÓN, J.: El califato de Córdoba. Cuadernos de Historia 16. 102. füzet, Madrid, 1985. 4. o. Issuu.com: https://bit.ly/3rtVytW

40. PERICOT, L. G. (dir.): Historia de España II. La alta edad media: siglos V al XIII. Instituto Gallach, Barcelona, 1970. 176. o.

41. ESCOLAR, H.: Historia de las bibliotecas. Fundación G. S. R., Madrid, 1987. 133. o.

42. SAMSÓ, J.: Ciencia musulmana en España. Cuadernos historia 16. 144. füzet, Madrid, 1985. 8. o. Issuu.com: https://bit.ly/31rc43m

43. CARLO, A. M.: Introducción a la historia del libro. Fondo de Cultura Económi-ca, Mexico-Madrid, 1993. 249-250. o.

44. DAMSEAUX - SOLANA: Historia de la pedagogia. Escuela Española, Madrid, 1967. 107. o. Iberlibro.com: https://bit.ly/39niAwF

45. L. erröl: MOLINA, A. M.: Córdoba de los Omeyas. Planeta, Barcelona, 1994.

46. PERICOT i. m., 234. o. | Goldziher Ignác: Az iszlám kultúrája I-II. címü müvé-ben, a spanyolországi muzulmánokról írott akadémiai székfoglalójában hu-szonnégy füzetet említett. Gondolat, Budapest, 1981. Antikvárium.hu: https://bit.ly/2QM6N11 | PTE OPAC — 930.8 G 50: https://bit.ly/3cq2sMC

47. VALDEÓN i. m., 28. o.

48. GOLDZIHER (1981) i. m., 142. o.

49. ESCOLAR i. m., 136. o. és MOLINA i. m., 112. o.

50. ESCOLAR i. m., 136. o.

51. ESTEBAN, L. - MARTÍN, R. L.: Historia de la enseñanza y de la escuela. Ti-rant lo Blanch, Valencia, 1994. 76. o. Editorial.tirant.com: https://bit.ly/3m53m4A 
52. ESCOLAR i. m., 138. o.

53. ESCOLAR i. m., 140. o.

54. Idézi: DÉVÉNYI - IVÁNYI i. m., 91. o.

55. IBN DZSÁIR-t idézi: CHEJNE, A. G.: Historia de España musulmana. Catedra, Madrid, 1993. 159. o.

56. BRENTJES, B.: Izmael fiai - Az arabok története és kultúrája. Kossuth, Buda-pest, 1986. 86. o. Antikvarium.hu: https://bit.ly/39jB5Cb | PTE OPAC — 930 B 88: https://bit.ly/31qv0iM

57. SZAID: Tabaqat al-Uman. Spanyolra fordította: Machado, O. A., spanyolból magyarra fordította: Kéri, K. In: SÁNCHEZ-ALBORNOZ, C.: La España mu-sulmana I. Espasa-Calpe, Madrid, 1978. 417. o. Iberlibro.com: https://bit.ly/3ruomTa

58. MOLINA i. m., 124. o.

59. ELLISSÉEFF és mások, i. m. 491-492. o.

\section{7. Önellenőrző tesztkérdések}

1. Mikor fejezödött be az iszlám szent könyve, a Korán végleges szövegváltozatának rögzítése?

[ ] Mohamed életében, még a 7. században.

[•] Csak a 10. századra.

[ ] A mongol hódítások 13. századi időszakában.

2. Hol állt a Bölcsesség Háza?

[•] Bagdad

[ ] Damaszkusz

[ ] Córdoba

\section{Mi jellemzö az arab irásra?}

[ ] Képírásjegyekből áll.

[ ] Tökéletes betüírás.

[•] Betük és mellékjelek rendszere.

4. Mi volt az iszlámban a legfóbb íráshordozó anyag a 11. századtól?

[ ] A papirusz

[ ] A pergamen

[•] A papír 


\section{Mit jelképezett a papir színe?}

[•] Az írás készítőjének/készíttetőjének nemét, rangját, az írás témáját.

[ ] Az írás megszületésének földrajzi helyszínét.

[ ] Semmit, nem volt jelentősége annak, milyen színü a papír.

6. Milyen forrásokból tudhatjuk, hogy a középkori iszlámban nagy érték volt a könyv.

[ ] Adóösszeírásokból.

[•] Irodalmi müvekből, képekről, tudományos müvekből.

[ ] Régészeti feltárások leleteiből.

7. Ki volt az a világhírü orientalistánk, aki a 19-20. század fordulóján Kairóban a könyvárusokról is irt?

[ ] Vámbéry Ádám

[•] Goldziher Ignác

[ ] Kákosy Lajos

8. Kiről kapta nevét a bagdadi Nizámijja könyvtár és tudományos központ?

[ ] Egy kalifáról, aki támogatta.

[•] Alapítójáról, egy vezírről.

[ ] Egy arab folyóról.

9. Melyik híres könyvtárról irt életrajzában a jeles orvos, Avicenna?

[ ] A bagdadi.

[ ] A jativai.

[•] A bokharai.

10. Hol müködtek a leghíresebb muszlim másolómühelyek al-Andalúszban?

[•] Córdoba, Sevilla, Granada, Toledo

[ ] Cádiz, Ronda, Malaga

[ ] Fuengirola, Tarifa, Alicante 


\section{Mi jellemezte leginkább al-Hakám córdobai kalifa uralkodásának idöszakát?}

[ ] Folyamatos háborúk, kaotikus társadalmi viszonyok.

[•] Tudományok, nevelésügy, könyvtárak bőkezü támogatása.

[ ] Pazarlás, beszedett adók elherdálása.

\section{Hogyan segítették a könyvtárak fenntartói a középkori tudósokat, diákokat?}

[ ] Sehogyan.

[ ] Ösztöndíjakkal.

[•] A könyvtárakban ingyenes papír- és írószerrel, vízzel.

13. Mi lett a sorsa a híres X. századi Córdobai könyvtárnak?

[•] A 11. században jórészt elégették, széthordták, kútba dobálták a könyvállományát.

[ ] Leégett a 15. században.

[ ] Ma is müködik, de már Kairóban. 